\title{
Mediators between Theoretical and Practical Medieval Knowledge: Medical Notebooks from the Cairo Genizah and their Significance
}

\author{
EFRAIM LEV* \\ Department of Eretz Israel Studies, University of Haifa, Haifa, 31905, Israel
}

\begin{abstract}
This article presents a plethora of fragments from the medical notebooks found in the Cairo Genizah that comprise a unique source of historical data for scholarly study and for a better understanding of the ways in which medieval medical knowledge in Egypt was transferred from theory to practice and vice versa. These documents provide the most direct evidence we have for preferred practical medical recipes because they record the choices of medical practitioners in medieval Cairo. Since the language most commonly used in them was Judaeo-Arabic, they were evidently written by Jews. The medical genre in the notebooks was primarily pharmacopoeic, consisting of apparently original recipes for the treatment of various diseases. There are also a few notebooks on materia medica. The subject matter of the Genizah medical notebooks shows that they were mostly of an eclectic nature, i.e. the writers had probably learnt about these treatments and recipes from their teachers, applied them at the hospitals where they worked or copied them from the books they read. Foremost among the subjects dealt with were eye diseases, followed by skin diseases, coughs and colds, dentistry and oral hygiene, and gynaecological conditions. The writers of the Genizah notebooks apparently recorded the practical medical knowledge they wished to preserve for their future use as amateur physicians, students, traditional healers or professional practitioners.
\end{abstract}

Keywords: Cairo Genizah, History of Medicine, Jewish, Medieval Middle East, Middle Ages, Notebook

* Email address for correspondence: elev@univ.haifa.ac.il

This article is dedicated to the late Mrs Shulie Reif, noble woman, talented editor, true friend and a wonderful hostess to many Genizah scholars in Cambridge for more than thirty years. I first met Shulie in Cambridge a decade ago when I started to learn about the medical issues in the Genizah. My research could not have been conducted without the devoted work of Sara Kemp who grew up in the Jewish community of Cairo and helped to transcribe the Genizah fragments. I express my deepest thanks to Stefan Reif, former head of the Taylor-Schechter Genizah Research unit, who helped me enter the world of Genizah research, and to Francis B. Brevart of the University of Pennsylvania, Monica Green of the Arizona State University, Peter Jones, Kings College, Cambridge; Avi Shivtiel, Leeds; Leigh Chipman of the Hebrew University in Jerusalem, Zohar Amar of Bar Ilan University in Israel, and Yaron Serri of Zefet Academic College in Israel, and especially the anonymous reviewers for their helpful remarks. Special thanks go to my colleagues at the Taylor-Schechter Genizah Research Unit at Cambridge University Library, who shared with me their enormous knowledge and experience and supported me with helpful comments: especially Ben Outhwaite (director of the Unit), the late Friedrich Niessen, Amir Ashur, Gabriele Ferrario, Esther-Miriam Wagner and Sara Sykes. I thank the Syndics of Cambridge University Library for permission to publish the Genizah fragments. 
Despite the loss of knowledge due to the extinction of ancient and medieval manuscripts, ${ }^{1}$ it is fortunate that our knowledge of medieval Arab medicine and pharmacology ${ }^{2}$ can be enhanced by a large repository of medical literature of that period found among the Cairo Genizah manuscripts, which cover a wide variety of subjects. These subjects include medical doctrines and theories, preventive medicine, the treatment of diseases and ailments, pharmacopoeias listing remedies and how to prepare them, materia medica and their different names, qualities and medical uses. Most of these medical compendia were written by learned physicians and pharmacists and intended both as teaching material and for reference purposes in the practical treatment and healing of patients.

The relationship between theory and practice in medieval medicine is an important topic for research and discussion. Even though most studies on the subject have dealt mainly with medieval European medicine, the potential value of the Cairo Genizah as a pertinent source for such discussion was noted. ${ }^{3}$

As a result of focused study over many years of the wealth of medical related manuscripts in the Cairo Genizah and the struggle to learn and distinguish between practical and theoretical texts, a new genre has now emerged that blurs the borderlines between them. Dozens of fragmented medical documents without strict theoretical characteristics or clear-cut practical ones were written by and served Jewish practitioners in medieval Cairo, mainly between the eleventh and thirteenth centuries. This was most probably the way these practitioners organised and recorded their preferred recipes in notebook form. I would therefore like to claim that this intermediary genre of medical notebooks lies precisely on the borderline between theora and practica, ${ }^{4}$ or theory and practice, ${ }^{5}$ and represent one of the ways, or alternatively one of the tools, by which theoretical medical knowledge became practical know-how and vice versa.

\footnotetext{
${ }^{1}$ John Cisne L., 'How Science Survived: Medieval Manuscript "Demography” and Classic Texts Extinction', Science, 307 (2005), 1305-7.

${ }^{2}$ Manfred Ullmann, Islamic Medicine (Edinburgh: Edinburgh University Press, 1978); Peter E. Pormann and Emilie Savage-Smith, Medieval Islamic Medicine (Cairo: The American University of Cairo Press, 2007); Savage-Smith Emilie, 'Medicine', in Roshdi Rashed (ed.), Encyclopedia of the History of Arabic Science (London/New-York: Routledge, 1996), 3:903-62; Emilie Savage-Smith, 'TTibb', The Encyclopaedia of Islam, 2nd edn (Leiden: Brill, 1999), 10, 456; Carl Brockelmann, Geschichte der Arabischen Litteratur (Leiden: Brill, 1898-1949), I, 230-40, 482-94, II, 170-2, 219, 242, 276-7, 333-5, 477-80, 545, 594-5, 617, I (suppl.) 412-26, 884-901, II, (suppl.) 168-70, 218-9, 252, 298-9, 326-7, 366-7, 491-3, 592-3, 625-7, 666-7, 713-4, 1027-32; Fuat Sezgin, Geschichte des Arabischen Schrifttums (Leiden: Brill, 1970), III, 3-340; Sami Hamarneh, 'The Rise of Professional Pharmacy in Islam', Medical History, 6 (1962), 59-63; Sami Hamarneh, 'Sources and Development of Arabic Medical Therapy and Pharmacology', Sudhoffs Archive, 54 (1970), 30-48; Sami Hamarneh, Origins of Pharmacy and Therapy in the Near East (Tokyo, 1973); Max Meyerhof, 'The Background and Origins of Arabian Pharmacology', Ciba Symposia, 6 (1973), 1847-56; Martin Levey, Early Arabic Pharmacology: An Introduction based on Ancient and Medieval Sources (Leiden: Brill, 1973); M. Ali and J.S. Qadry, 'Contribution of Arabs to Pharmacy', Studies in History of Medicine, 6 (1982), 43-53; Michael Rogers, 'The Arab Contribution to Botany and Pharmacology', Arab Affairs, 6 (1988), 71-81; Oliver Kahl, The Dispensatory of Ibn at-Tilmī․: Arabic Text, English Translation, Study and Glossaries (Leiden/Boston: Brill, 2007); Leigh Chipman, World of Pharmacy and Pharmacists in Mamlūk Cairo (Leiden: Brill, 2009).

3 John M. Riddle, 'Theory and Practice in Medieval Medicine', Viator, 5 (1974), 157-84.

${ }^{4}$ Luke Demaitre, 'Theory and Practice in Medical Education at the University of Montpellier in the Thirteenth and Fourteenth Centuries', Journal of the History of Medicine, 30 (1975), 103-23.

${ }^{5}$ Danielle Jacquart, 'Theory, Everyday Practice, and Three Fifteenth-Century Physicians', Osiris, 6 (1990), 140-60; Andrew Cunningham, 'The theory/practice of medicine: division of medicine: two late Alexandrian legacies,' in Teizo Ogewa (ed.), History of Traditional Medicine (Tokyo: the Taniguchi Foundation, 1986), 303-24; Jole Agrimi and Chiara Crisciani, Edocere medicos; Medicina scolastica nei secoli XIII-XV (Naples: Guerini e associati, 1988), 21-47.
} 
A study of Graeco-Roman case-histories in medical literature reveals that during the process of assimilation of classical and Hellenistic medicine into the medieval Islamic medical tradition, it was not only the theoretical principles that were adopted but also the literary models for presenting medical knowledge, including the case-history model. According to Alvarez-Millan who compared the case histories of Rufus of Ephesus and Galen with those by the tenth century Islamic physician al-Rāzī [Rhazes] (Kitāb alTajärib), the clinical records of the latter constituted an instrument with which to study and expand medical knowledge as well as to provide useful material for the medical training of students. ${ }^{6}$ Alvarez-Millan also studied the description of diseases occurring in the al-Rāzî casebook: the largest and oldest collection of case histories known in medieval Islamic medical literature. By comparative analysis, she showed that the medical knowledge and the therapeutic advice so meticulously described in theoretical works were not comparable to the physician's medical performance. On the contrary, it appears that learned treatises served purposes other than that of determining medical practice. ${ }^{7}$

Medicine and disease in medieval Islam have thus far been approached through theoretical medical treatises, with the assumption that learned medical texts are a transparent reflection of the actual practice of medicine. The extent to which the ideas and theoretical principles in those treatises were actually carried out in practice has yet to be explored adequately. Other research, which dealt with and analysed 260 Greek medical papyri of a theoretical and practical nature found in Egypt (third century BC-seventh century $\mathrm{CE}$ ), showed that these Greek recipes were not solely based on the classical medical tradition but also on local Egyptian pharmacopoeias. ${ }^{8}$

\section{Medical Documents in the Cairo Genizah}

For hundreds of years, especially during the rule of the Fātimids, Ayyūbids and Mamlūks over Egypt, the Jewish community in the country, mainly in Cairo and Alexandria, existed as one of the most important centres of Jewry in the world. The community maintained extensive internal and international ties and engaged in widespread social, economic and religious activity. The Jews of Fustạt (Old Cairo) worshipped in a few synagogues, one of which was named the 'Ben Ezra' synagogue that served as the centre of the 'Palestinian' Jewish community. This community had used the same building as their religious centre for almost a millennium, and during that time assigned one of the upper rooms as a 'Genizah', or repository for discarded handwritten material. As prescribed by Jewish religious custom observed in all Jewish communities around the world since early times, sacred books no longer in use were to be either deposited in a Genizah or buried. The community in Fusțât made use mainly of the first option, and expanded it in such a way that almost every piece of writing, whether secular or religious, which passed through the hands of its members was consigned to the Genizah. Fortunately enough,

\footnotetext{
${ }^{6}$ Cristina Alvarez-Millan, 'Graeco-Roman Case Histories and their Influence on Medieval Islamic Clinical Accounts', Social History of Medicine, 12 (1999), 19-43.

${ }^{7}$ Cristina Alvarez-Millan, 'Practice versus Theory: Tenth-century Case Histories from the Islamic Middle East', Social History of Medicine, 13 (2000), 293-306.

${ }^{8}$ Isabella Andorlini, 'Prescription and practice in Greek medical papyri from Egypt', in Harald Froschauer and Cornelia Römer (eds), Zwischen Magie und Wissenschaft: Ärzte und Heilkunst in den Papyri aus Ägypte (Wien: Phoibos, 2009), 23-33.
} 
due to the dry climate of Egypt, vast quantities of these manuscripts were preserved. ${ }^{9}$ During the nineteenth century the fragments slowly found their way into the hands of private collectors, and soon different academic institutes and libraries were assembling their own collections. ${ }^{10}$ The Genizah documents touch on almost all social, cultural and economic aspects of life, including medicine, in medieval Mediterranean communities. The importance of their discovery was further highlighted by the fact that Jews constituted one of Egypt's significant minorities. The community not only mirrored Mediterranean society as a whole but was also famed for its medical heritage and its learned physicians. ${ }^{11}$

The potential of the Genizah collection for the study of medical issues has already been noted by several scholars. ${ }^{12}$ However, little in-depth research seems to have been conducted to explore actual medieval medical practices. The approximately 1800 medical documents extracted so far in the Taylor-Schechter (T-S) Genizah Collection in the Cambridge University Library, ${ }^{13}$ comprising 'in situ fossils of medical knowledge', ${ }^{14}$ provide a direct insight into medieval medical theory and practice, mainly from the eleventh to the thirteenth century, and reveal a unique potential for resurrecting lost knowledge. ${ }^{15}$

In 2003 a new interdisciplinary project was launched in Cambridge dealing with medical issues in the lives of the people portrayed in the Genizah manuscripts. A team of scholars from various fields, including historians, medical historians, linguists and biologists, are now at work identifying, categorising, studying, editing and publishing papers on the numerous fragments concerned with medicine in the Genizah collections. As a founder of that team, I have studied three Genizah collections in the UK for my research on medieval

\footnotetext{
${ }^{9}$ Stefan C. Reif, A Jewish Archive from Old Cairo: The History of Cambridge University's Genizah Collection (Richmond: Curzon Press, 2000), 1-22.

${ }^{10}$ Binyamin Richler, Guide to Hebrew Manuscript Collections (Jerusalem: Israel Academy of Sciences and Humanities, 1994).

${ }^{11}$ Shelomo Dov Goitein, A Mediterranean Society (Berkeley: University of California Press, 1967-88), I, 153-4; 209-24; II, 240-72.

12 Albert Dietrich, Zum Drogenhandel Im Islamischen Agypten (Heidelberg: Carl Winter, 1954); Shelomo Dov Goitein, 'The Medical Profession in the Light of the Cairo Genizah Documents', Hebrew Union College Annual, 34 (1963), 177-94; Fenton Paul, 'The Importance of the Cairo Genizah for the History of Medicine', Medical History, 24 (1980), 347-48; Estee Dvorjetski, 'The contribution of the Geniza to the study of the medicinal hot springs in Eretz-Israel', in Proceedings of the Twelfth World Congress of Jewish Studies (Jerusalem: World Union of Jewish Studies, 1990), II, 85-93; Mark R. Cohen, 'The Burdensome Life of a Jewish Physician and Communal Leader: A Geniza Fragment from the Alliance Israelite Universelle Collection', Jerusalem Studies in Arabic and Islam, 16 (1993), 125-36; Colin Baker, 'Islamic and Jewish Medicine in the Medieval Mediterranean World: The Genizah Evidence', Journal of the Royal Society of Medicine, 89 (1996), 577-80; Haskell D. Isaacs, 'A Medieval Arab Medical Certificate', Medical History, 35 (1991), 250-7.

${ }^{13}$ Haskell D. Isaacs, (with the assistance of Baker Colin F.), Medical and Para-Medical Manuscripts in the Cambridge Genizah Collections (Cambridge: Cambridge University Press, 1994); Friedrich Niessen and Efraim Lev, 'Addenda to Isaacs Catalogue, 'Medical and Para-medical Manuscript in the Cambridge Genizah Collection Together with the Edition of Two Medical Documents T-S 12.33 and T-S NS 297.56', Hebrew Union College Annual, 77 (2008), 131-65.

14 Sharon Larimer Gilman and Florence Eliza Glaze, 'How Science Survived: Medieval Manuscripts as Fossils', Science, 307 (2005), 1208-9.

15 Efraim Lev and Zohar Amar, 'Fossils' of Practical Medical Knowledge from Medieval Cairo', Journal of Ethnopharmacology, 119 (2008), 24-40.
} 
medicine in Egypt and the Mediterranean region: the T-S Genizah Collection; ${ }^{16}$ the John Rylands Cairo Genizah collection; ${ }^{17}$ and the Mosseri collection. ${ }^{18}$

A few genres of medical fragments were defined such as books, ${ }^{19}$ prescriptions, ${ }^{20}$ lists of drugs and correspondence. ${ }^{21}$ This article will focus on medical notebooks that form an intermediate genre between books and prescriptions since they do not easily fit into any of the fragment categories described above. Most of the notebooks, which consist of a few dozen fragments identified in the Cairo Genizah, create the opportunity to study another aspect of medieval medicine.

Through my study and analysis of the medical fragments from the Cairo Genizah, a methodology was gradually devised for distinguishing between the various kinds of information derived from them and for differentiating between theoretical and practical medical knowledge. ${ }^{22}$

A. Theoretical knowledge of medicine is purported to be mainly contained in general medical books which provide information regarding the basics in medicine and pharmacology. 'Theoretical medical knowledge' can be defined as information and medical expertise transmitted in writing by experienced scholars, mainly in medicine and pharmacology, whose main objective was that of teaching and directing medical students and of safeguarding the medical knowledge that had been accumulated, developed or practised by them for future reference. Jones, in his research on medieval English medical books, says that: 'Academic medical books are admirably suited to teaching and learning, but not to the problems faced by our medical practitioner when treating patients.' 23

To date, about 1360 fragments of medical books have been identified in the T-S collections and dozens in each of the other collections mentioned above. These books were copied or translated from works written by classical or medieval physicians and pharmacologists. Most of the books are written in Arabic (740), fewer in Judaeo-Arabic

\footnotetext{
${ }^{16}$ Richler, op. cit. (note 10), 60-4; Isaacs, op. cit. (note 13); Niessen and Lev, op. cit. (note 13).

17 John Rylands University Library, A Guide to Special Collections of The John Rylands University Library of Manchester (Manchester: John Rylands University Library, 1999); Efraim Lev and Renate Smithuis, 'A Preliminary Catalogue of the Medical and Para-medical Manuscripts in the Rylands Genizah Collection, Together with the Partial Edition of Two Medical Fragments (B 3239 and A 589)', Journal of Semitic Studies (forthcoming).

${ }^{18}$ Efraim Lev, 'A Catalogue of the Medical and Para-Medical Manuscripts in the Mosseri Genizah Collection, together with several unpublished examples (X.37; I.124.2)', Journal of Jewish Studies, 62 (2011), 121-45.

${ }^{19}$ Efraim Lev, 'Work in progress - the research of medical knowledge in the Cairo Genizah - past, present and future', in Shulie Reif (ed.), The Written Word Remains: The Archive and the Achievement (Cambridge: University of Cambridge Library, 2004), 37-51.

${ }^{20}$ Prescription in this article is defined as practical remedy (written by practitioners for a patient), while recipe is the 'theoretical' form, ie. formula of remedy found in books and notebooks. About practical prescription found in the Genizah see: Efraim Lev, 'Medieval Egyptian Judaeo-Arabic Prescriptions (and Edition of Three Medical Prescriptions)', Journal of Royal Asiatic Society, 18, 4 (2008), 449-64; Leigh Chipman and Efraim Lev, 'Arabic Prescriptions from the Cairo Genizah', Asian Medicine, 6 (2011), 75-94.

${ }^{21}$ Efraim Lev, 'Drugs Held and Sold by Pharmacists of the Jewish Community of Medieval (11th-14th centuries) Cairo According to Lists of Materia Medica Found at the Taylor-Schechter Genizah Collection, Cambridge', Journal of Ethnopharmacology, 110 (2007), 275-93; Amir Ashur and Efraim Lev, 'New Genizah Documents: Three Fragments on Practical Medicine in Medieval Egypt', Ginzie Qedem, 9 (2013), 9*-35*.

${ }^{22}$ Efraim Lev and Zohar Amar, 'Practice Versus Theory: Medieval Materia Medica According to the Cairo Genizah', Medical History, 51 (2007), 507-26.

${ }^{23}$ Peter M. Jones, 'Harley MS 2558: a fifteenth-century medical commonplace book', in Margaret R. Schleissner (ed.), Manuscript Sources of Medieval Medicine (New York/London: Garland, 1995), 35-54.
} 
$(470)^{24}$ and the rest in Hebrew (150). About sixty titles of medical books have been identified so far: thirty-five titles by Isaacs, ${ }^{25}$ about fifteen more titles by my Cambridge team, ${ }^{26}$ another dozen of titles in other Genizah collections around the world and the work of identification is still an ongoing process. Of the titles already identified, roughly one third of the books were written by classical authorities such as Galen and Hippocrates and another third were written by Muslim writers such as Sābūr Ibn Sahl (ninth century), ${ }^{27}$ Ibn Sīnā (tenth-eleventh century), al-Rāzī, Ibn al-Baytār (thirteenth century) and 'Alī Ibn 'Isa (tenth-eleventh century). The rest were written by Jewish physicians, members of the Cairo Jewish community, such as Kūhin al-'Atțār al-Isrā'îlī (a thirteenth century Jewish physician active in Egypt), ${ }^{28}$ Dawūd Ibn Abī al-Bayān (a twelfth-thirteenth century Karaite physician active in Cairo; see figure 1) ${ }^{29}$ and Maimonides (twelfth century). ${ }^{30}$

Further titles of medical books used by members of the medieval Jewish community of Cairo can be found in the lists that record the books owned by medical practitioners or private persons and that had subsequently been sold after their death. A few dozen of such lists, all written in Judaeo-Arabic, include information on medical books and are being currently studied. ${ }^{32}$ One special and unique list of books that belonged to a local Jewish physician has been published. ${ }^{33}$

Medical books include subjects such as physiology, methods of diagnosis, healing doctrines and so on. They also include suggested recipes for the treatment of various diseases and ailments and information regarding medicinal substances, the quality and uses of which were accredited to known practitioners. I would like to argue that the medical books identified as such in the Cairo Genizah belong to the category of theoretical medical literature. The study of this medical literature can teach us about the quantities,

\footnotetext{
${ }^{24}$ Judaeo-Arabic is a collection of Arabic dialects spoken by Jews living in Arabic-speaking countries. See, Joshua Blau, The Emergence and Linguistic Background of Judaeo-Arabic: A Study of the Origins of Neo-Arabic and Middle Arabic, 1st edn (Oxford: Oxford University Press, 1965); 3rd edn (Jerusalem: Ben-Zvi Inst., 1999); Joshua Blau, Studies in Middle Arabic and its Judaeo-Arabic Variety (Jerusalem: Magnes Press, 1988).

25 Isaacs, op. cit. (note 13).

${ }^{26}$ Lev, op. cit. (note 20).

${ }^{27}$ Efraim Lev and Leigh Chipman, 'A Fragments of Judeo-Arabic Manuscripts of Sābūr Ibn Sahl al-Aqrābādhīn al-Saghīr Found in the Taylor-Schechter Cairo Genizah Collection', Medieval Encounter, 13 (2007), 347-62; Leigh Chipman and Efraim Lev, 'Take a Lame and Decrepit Hyena.... A Genizah Study of Two Additional Fragments of Manuscripts of Sābūr Ibn Sahl al-Aqrābādhīn al-Ṣaghīr', Early Science and Medicine, 13 (2008), 361-83.

${ }^{28}$ Leigh Chipman and Efraim Lev, 'Syrup from the Apothecary's Shop: A Genizah Fragment Containing one of the Earliest Manuscripts of Minhaj al-dukkan', Journal of Semitic Studies, 50 (2006), 137-67.

${ }^{29}$ Dawūd Ibn Ab̄̄ al- Bayān, al-Dustūr al-Bīmāristānī (Arabic), in Paul Sbath (ed.) 'Le Formulaire des hôpitaux d'Ibn abil Bayan, médicin du bimaristan annacery au Caire au XIIIe siècle', Bullétin de l'Institut d'Egypte, 15 (1932-3), 9-78. See Efraim Lev Leigh Chipman and Friedrich Niessen, 'A Hospital Handbook for the Community: Evidence for the Extensive Use of Ibn Abī 'l-Bayān's al-Dustūr al-Būmāristānı̄ by the Jewish Practitioners of Medieval Cairo', Journal of Semitic Studies, 53 (2008), 103-18.

${ }^{30}$ Samuel Miklos Stern, Corpus Codicum Hebraicorum Medii Aaevi (Hafniae: Sumptibus E. Munksgaard, 1956), Part 1, Vol. 3, 12-17; Shlomo Dov Goitein, 'Maimonides Life in the Light of the Geniza Documents', Peraqim, 4 (1966), 29-42.

${ }^{31}$ For more details, see Lev, Chipman and Niessen, op. cit. (note 29); for transcription and translation, see Niessen and Lev, op. cit. (note 13).

32 Miriam Frenkel, 'Book Lists from the Genizah as a source for the culture and social history of the Jews in Mediterranean society', in Mordechai Friedman (ed.), A Century of Genizah Research, Te'uda, XV (Tel Aviv: Tel Aviv University Press, 1999) (Hebrew); Nehemiah Allony, The Jewish Library in the Middle Ages: Book Lists from the Cairo Genizah, Miriam Frenkel, Haggai Ben-Shammai with the participation of Moshe Sokolow (eds) (Jerusalem: Makhon Ben-Zvi le-heker Kehilot Yiśra'el ba-mizrah, 2006) (Hebrew).

33 David H. Baneth, 'A Doctor's Library in Egypt at the Time of Maimonides', Tarbiz, 30 (1961), 171-85.
} 


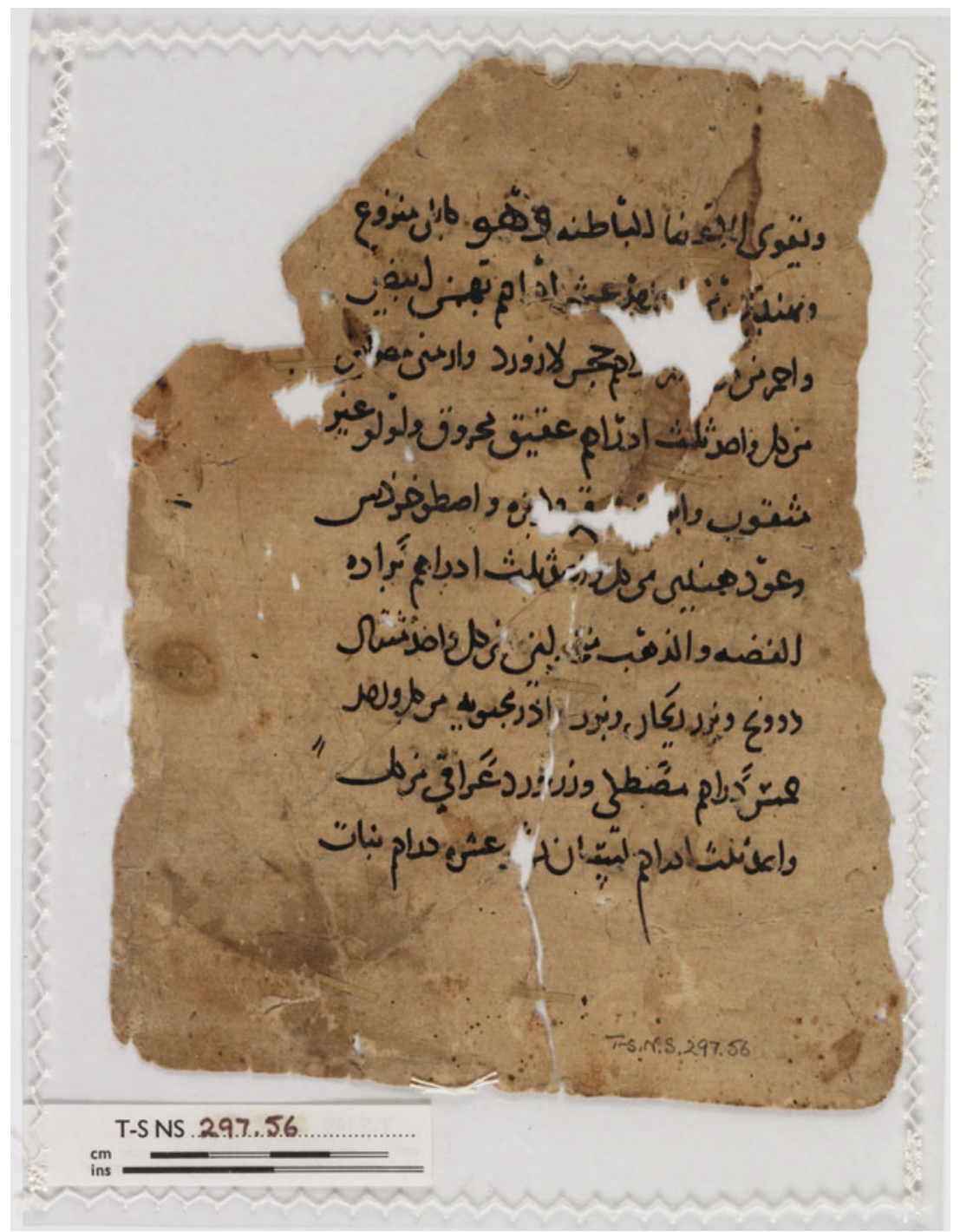

Figure 1: Page of a medical book: Dawūd Ibn Abi al-Bayān's al-Dustūr al-Bīmāaristān̄̄ (T-S NS 297.56). ${ }^{31}$

qualities and level of medical knowledge that was available to the medical students and practitioners of that time or, in other words, could be termed as their 'intellectual medical workshop'. According to Jones, medieval books, especially in England and Europe, were usually large and lengthy tomes, expensive to buy and not very portable. They could not be used for quick reference purposes because it would be difficult to access the required information, ${ }^{34}$ since most of the information about medication and ailments was often scattered in large tomes, for example in Ibn Sīnā (Avicenna)'s Canon. ${ }^{35}$

34 Jones, op. cit. (note 23), 36.

35 Ibn Sīnā, Abū 'Alī al-Ḥusayn b. 'Abdallāh. al-Qānūn fì 'l-ṭi bb (Beirut: Dār al-Kutub al-'Ilmiyya, 1999); Nancy G. Siraisi, Avicenna in Renaissance Italy. The Canon and Medical Teaching in Italian Universities after 1500 (Princeton: Princeton University Press, 1987), 21-3. 
From the methodological point of view, and according to my experience, medical books in general are distinguishable from the medical fragments found in the Genizah by certain unique features:

- The text in the medical books is usually longer than in prescriptions, letters and notebooks;

- In most cases the page layout is nicely done, the text is well set out and written in a professional style in a clear and fine handwriting, the number of lines is fixed, and the margins are straight;

- The text is written on both sides of the paper and occasionally on bi-folium;

- All fragments that are pages of the same book are of the same size;

- The text is written by one hand and in one language;

- The text is usually written in the same colour ink (apart from important words or headings written in some cases in other colours);

- Occasionally, a catchword ${ }^{36}$ is presented at the bottom of each page;

- The text is organised in book form, with volume, chapter and section headings. ${ }^{37}$

B. Practical or 'clinically useful medical knowledge' is commonly found in prescriptions, lists of drugs and private correspondence written by medical practitioners such as physicians and pharmacists as part of their daily work. This comprised treating patients or preparing drugs. Such documents, mainly prescriptions, record their actual work and consequently can be considered an important element of medical knowledge in its practical form. ${ }^{38}$

Prescriptions form the main bulk of the fragments of a practical character. There are 141 unique original prescriptions in the T-S Genizah collection, of which thirty were more or less complete: ${ }^{39}$ eighty-three written in Arabic (see for example figure 2), fifty-six in Judaeo-Arabic, ${ }^{40}$ one in Judaeo-Persian and one in Hebrew. ${ }^{41}$ A few more were discovered in the other collections.

Only a few prescriptions were copied identically, others contained changes derived from

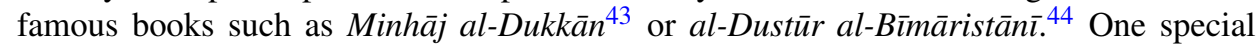

\footnotetext{
${ }^{36} \mathrm{~A}$ word written at the bottom of a page that repeats the first word of the following page.

${ }^{37}$ For codicological terminology used in this work see: Adam Gacek, Arabic Manuscripts: A Vademecum for Readers (Leiden/Boston: Brill, 2009); François Déroche, Islamic Codicology: an Introduction to the Study of Manuscripts in Arabic Script, Deke Dusinberre and David Radzinowicz (trans.), in Muhammad Isa Waley (ed.) (London: Al-Furqān Islamic Heritage Foundation, 2006); Malachi Beit-Aria, Hebrew Codicology: Tentative Typology of Technical Practices Employed in Hebrew Dated Medieval Manuscripts (Jerusalem: Israel Academy of Sciences and Humanities, 1981).

${ }^{38}$ Efraim Lev and Zohar Amar, 'Reconstruction of the Inventory of Materia Medica used by Members of the Jewish Community of Medieval Cairo According to Prescriptions Found in the Taylor-Schechter Genizah Collection, Cambridge', Journal of Ethnopharmacology, 108 (2006), 428-44.

${ }^{39}$ Efraim Lev and Leigh Chipman, Medical Prescriptions in the Cambridge Genizah Collections: Practical Medicine and Pharmacology in Medieval Egypt (Leiden: Brill, 2012).

${ }^{40}$ The figures here are different from previous publications since, as in other research projects, our Genizah study is a dynamic process. In the last three years, several additional fragments in Arabic script have been identified as prescriptions, while several Judaeo-Arabic documents formerly considered to be prescriptions have been reclassified as notebooks.

${ }^{41}$ For a full discussion of these, see Lev, op. cit. (note 19); Chipman and Lev, op. cit. (note 19); Efraim Lev and Zohar Amar, Practical Materia Medica of the Medieval Eastern Mediterranean According to the Cairo Genizah (Leiden: Brill, 2008), 43-8.

42 A full edition of this fragment is published in Lev and Chipman, op. cit. (note 39), pp. 52-4.

43 al-Kūhin al-'Aț̣ạ̄r, Abu 'l-Munā Dāwūd b. Abī Naṣr. Minhāj al-dukkān wa-dustūr al-a'yan fí a'māl wa-tarākīb al-adwiya al-nāfi'a li-'l-insān. Ḥ. al-'Āsị (ed.) (Beirut: Dār al-Manāhil, 1992).

44 al-Bayān, op. cit. (note 29).
} 


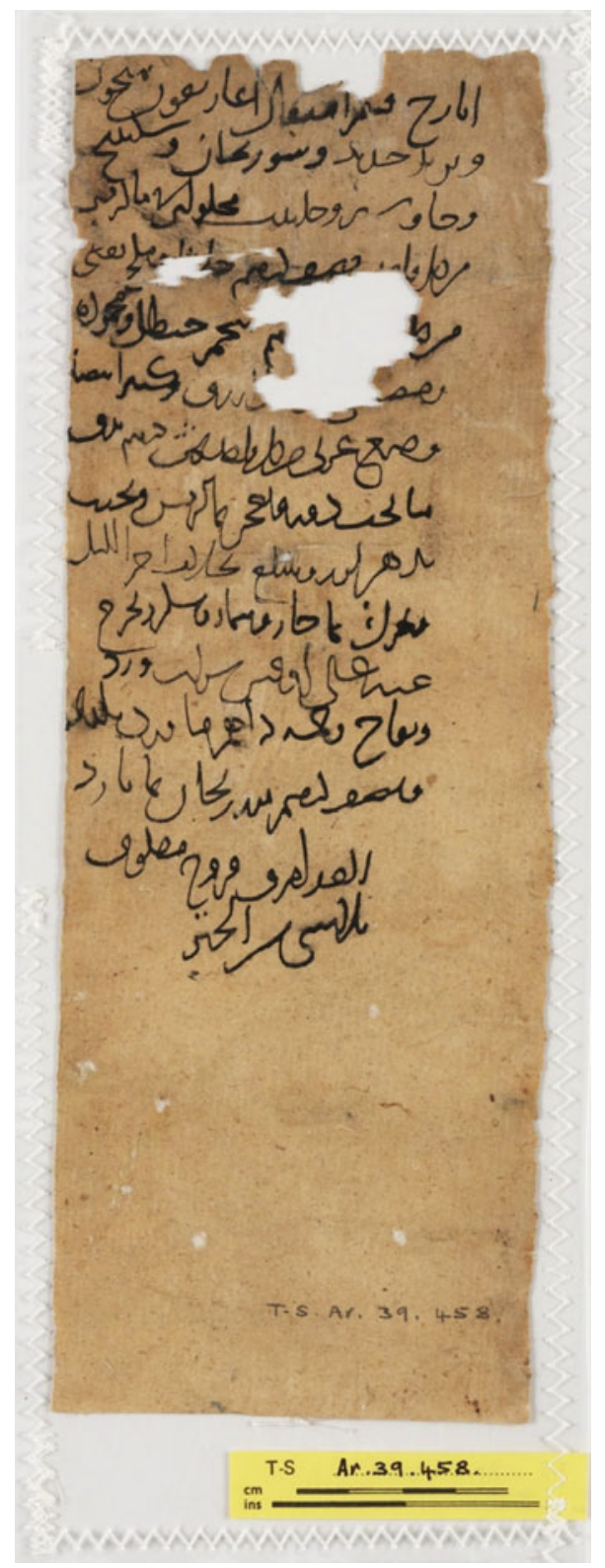

Figure 2: Practical prescription (T-S Ar.39.458). ${ }^{42}$

prescription written for a dozen patients was also discussed in a separate publication. ${ }^{45} \mathrm{~A}$ unique aspect of the information that emerges from the prescriptions is their originality. Unlike the information derived from books which is usually copied from classical or

${ }^{45}$ Efraim Lev, Leigh Chipman and Friedrich Niessen, 'Chicken and Chicory are Good for You: A Unique Family Prescription from the Cairo Genizah (T-S NS 223.82-3)', Jerusalem Studies in Arabic and Islam, 35 (2008), 335-52. 
contemporary medical sources, the prescriptions are clear-cut primary evidence for the medicinal substances actually in use, 242 of which are mentioned. These prescriptions can therefore be considered as solid evidence of the use of these substances for medicinal purposes and of medical knowledge in its practical form. ${ }^{46}$

The features which enabled us to identify Genizah fragments as prescriptions have already been discussed in previous publications. ${ }^{47}$

Prescriptions can also teach us about the prevailing diseases and their symptoms that were actually suffered by members of the community. 48

Prescriptions are rarely preserved since they lose their importance the moment they are used; finding such documents in the Genizah can be described as the 'survival of ephemeral documents'. It is a rare opportunity for historians of medicine to be able to read and analyse records of the immediate interaction between the physicians who wrote out the prescriptions and their patients who presumably took the prescriptions to apothecaries for the purchase or preparation of the formula. The prescriptions are in fact autographs from the prescribing physicians themselves. They come about as close to the ipsissima verba of medieval physicians as we are likely to get. It is a reflection of the medical reality that actually existed, which at times corresponds with the information found in books.

Previous research in the history of medicine in the Genizah clearly show that the practical inventory of materia medica was smaller (278) than the theoretical inventory (414), which was based on the books that physicians possessed. In other words, the Genizah allows us for the first time to quantify the difference between the practical and theoretical inventories which comes to 136 simple drugs $(33 \%) .{ }^{49}$

Presented below is a plethora of Genizah fragments consisting of medical notebooks that, thanks to the quantity of the documents, their originality and the historical knowledge, comprise a unique source of historical data from which scholars can learn and better understand the way medieval Arab medical knowledge was transferred from theory to practice and vice versa. This specific genre has hardly been known or dealt with in research to date. An attempt will therefore be made here to elucidate the following questions that will allow us to place the documents within the context of this medieval community and of Mediterranean society in general during that particular period:

- Who wrote the medical notebooks found in the Cairo Genizah, for what purpose and what was their language of preference?

- Where did the recipes in the notebooks originate from?

- What kind of medical knowledge was recorded in the medical notebooks and what were the main medical topics that were of concern to them?

\footnotetext{
${ }^{46}$ Lev and Amar, op. cit. (note 38).

${ }^{47}$ Most of the prescriptions were written on one page, usually on one side of the sheet of paper and very rarely on vellum, and in one case even on a piece of cloth. Prescriptions were often written on reused paper, sometimes in the margin or in between the lines of other documents or even books. The handwriting is usually sloppy and unclear; see Lev and Amar, op. cit. (note 41), 45-6.

48 Analysis of the prescriptions with the help of contemporary pharmacopoeias shows that eye diseases were the most prevalent ailments. Other ailments were skin diseases, headaches, fevers, internal diseases (liver), intestinal problems, and haemorrhoids, urinary problems, ulcers, swellings, cough and gynaecological illnesses; see ibid., $46-7$.

${ }^{49}$ Ibid., 550-8.
} 


\section{Medical Notebooks in the Cairo Genizah}

Sixty-one medical notebooks were identified: fifty in the T-S Genizah collection, ${ }^{50}$ nine in the Mosseri collection, ${ }^{51}$ and two in the John Rylands University Library in Manchester. ${ }^{52}$ This is roughly $3 \%$ out of about 2040 medical fragments that are found in these collections. 53

\section{Discussion}

A notebook in the modern sense is a booklet of plain paper used for writing notes. ${ }^{54}$ Such booklets were already used in ancient Greece in parchment form. One early example is Pliny's first century description of the 'private notebook' of Mithridates found by Pompey which included a prescription for the famous antidote against poisoning. ${ }^{55}$

In early Islamic times the word daftar ${ }^{56}$ seems to have been used to denote the codex form of a book or booklet, as opposed to rolls and loose sheets. With the development of elaborate bureaucratic organisations, the keeping of daftars became a task calling for special skills and knowledge and consequently daftars of many different varieties began to emerge. ${ }^{57}$

Very little is written about notebooks in the Arabic scholarly tradition in contrast with the vast literature dealing with books. ${ }^{58}$ Gunther mentions that, as part of the oral and written transmission of knowledge, teachers in Early Islam based their lectures and seminars on "collections" of data and "lecture scripts" that were organised in notebook form. ${ }^{59}$ As an example of this, he suggests that Abū l-Faraj al-'Isfahānī (tenth century),

${ }^{50}$ T-S K14.32; T-S K25.83; T-S Ar.11.11; T-S Ar.35.226; T-S Ar.39.20; T-S Ar.39.367; T-S Ar.39.451; T-S Ar.42.20; T-S Ar.42.67; T-S Ar.43.28; T-S Ar.43.42; T-S Ar.44.30; T-S Ar.44.182; T-S Ar.44.222; T-S Ar.45.21; T-S Ar.45.30; T-S Ar.45.40; T-S Ar.50.171; T-S AS 147.204; T-S AS 148.111; T-S AS 150.136; T-S AS 159.235; T-S AS 160.197; T-S AS 163.199; T-S AS 179.262; T-S Or.1080 7.17; T-S Or.1081.1.78; T-S NS 90.23; T-S NS 90.51; T-S NS 90.64; T-S NS 90.73; T-S NS 90.74; T-S NS 91.6; T-S NS 163.116; T-S NS 164.159; T-S NS 190.26; T-S NS 224.146; T-S NS 224.149; T-S NS 224.226; T-S NS 225.108; T-S NS 264.27; T-S NS 265.27; T-S NS 265.62; T-S NS 297.48; T-S NS 314.6b; T-S NS 322.31; T-S NS 324.128; T-S NS 339.62; T-S NS J89; T-S NS J 543.

${ }^{51}$ I, 111; I, 112; I, 113; I, 114.2; I, 126.1; I, 127.1; I, 127.2; I, 128.1; IV, 339.2.

52 B 3238-1-2; B 3239-1-2.

${ }^{53}$ However, as mentioned before some fragments are very small and they might be from books (eg., TS NS 90.73 and TS NS 90.74). The same holds for more fragments identified as notebooks, but being well arranged and set may likewise be from books (T-S Ar.44.182; T-S Ar.45.187, T-S Or.1080.7.17; T-S AS 148.28; T-S NS 190.26; T-S NS 210.29).

54 Oxford Paperback Dictionary: Thesaurus, and Wordpower Guide (Oxford, 2001), 604; Cambridge Dictionary online (http://dictionary.cambridge.org/).

55 Pliny, Natural History, XXIII, 77: 149, William H.S. Jones (trans.) (Cambridge, Mass./London: Heinemann, 1969), 515.

${ }^{56}$ In the Arabic tradition daftar is described as 'a stitched or bound booklet or register. .. an account or letterbook used in administrative offices...' see Bernard Lewis, 'Daftar', Encyclopaedia of Islam, 2nd edn, in P. Bearman, Th. Bianquis, C.E. Bosworth , E. van Donzel and W.P. Heinrichs (eds) (Leiden: Brill, 2010), II, 77.

57 Ibid.

${ }^{58}$ George Nicholas Atiyeh (ed.), The Book in the Islamic World: the Written Word and Communication in the Middle East (Albany: Library of Congress, 1995); Jonathan M. Bloom, Paper before Print: the History and Impact of Paper in the Islamic World (New Haven/London: Yale University Press, 2001); Johannes Pedersen, The Arabic Book, Geoffrey French (trans.) (Princeton: Princeton University Press, 1984); Déroche, op. cit. (note 37).

${ }^{59}$ Sebastian Gunther, 'Assessing the Sources of Classical Arabic Compilations: The Issue of Categories and Methodologies', British Journal of Middle Eastern Studies, 32, 1 (2005), 75-99, 78. 
when writing his book Maqātil at-Talibīn [The Killing of the Talibids], ${ }^{60}$ used notebooks that al-Thaqafī (tenth century) had written. ${ }^{61}$ Similarly, Abū l-Faraj al-Isfahānī sometimes quotes at length from al-Nawfalī (ninth century); according to Gunther these passages may have been drawn from his teacher's works or even from the notebooks he prepared when he was a student. ${ }^{62} \mathrm{Al}$-Ṭabarī (ninth-tenth century) also relied on presumably unpublished 'books' when transmitting information: 'Like other students and scholars, al-Ṭabarī kept his notebooks and occasionally made a reference to them'. ${ }^{63}$ Another case is Abū Hayyān al-Tawhīdī (tenth century), who 'burned his books at the end of his life...' According to Rosenthal these include unpublished manuscripts, such as notebooks and drafts. ${ }^{64}$

A few scholars discussed the issue of 'household books' that circulated within the lay realm in medieval England. Boffey for example described such books as 'A repository of practical information of more or less domestic kinds - recipes and remedies and instructions on matters such as dyeing, fishing.... ${ }^{65} \mathrm{~A}$ similar genre for such books was known in the West and termed by several scholars as 'commonplace books'. Some of these fifteenth-century manuscripts in England were studied, and according to Jones the way that some of them were compiled 'throws a great deal of light on the integration of practical experience... with the fruits of his own reading of medical texts' ${ }^{66}$

In Europe, 'commonplace books' were used by Renaissance scholars in a similar way for collating and preserving poems written by a large number of poets. In most cases, neither the owners' nor the poets' names were recorded. According to Thomas, such 'commonplace books' were dynamic in character and always receptive to a new poem or the improvement of an existing one. He also states that these, 'are about memory... like a record of what that memory might look like'. ${ }^{67}$ According to Blair, 'commonplace books' in the Renaissance were used as a 'humanistic method of reading and storing information'. The method, similar to that of our medical notebooks, was to select passages of interest, dialectical arguments, or factual information, and copy them for later use. Blair also asserts that the method was learnt from the classical science of rhetoric and had a similar use in medieval times when it also served, as 'in the case of medical handbooks', to record 'recipes compiled for easy access'. ${ }^{68}$ Schiffman adds that quite often separate notebooks

\footnotetext{
${ }^{60}$ Sebastian Gunther, 'Maqatil-Literature in Medieval Islam', Journal of Arabic Literature, 25, 3 (1994), 193-212.

61 Ibid., 193

62 Sebastian Gunther, 'Al-Nawfalī’s Lost History. The Issue of a 9th Century Shiite Source Used By al-Ṭabari and Abu 1-Faraj', British Journal of Middle Eastern Studies, 36.2 (2009), 241-66, 252, 263.

63 Gunther, op. cit. (note 62), 263; al-Tabarī, General Introduction, and, From the Creation to the Flood, Franz Rosenthal (trans.) (Albany, 1989), I, 6, 52.

${ }^{64}$ Franz Rosenthal, “'Of making many books there is no end”: the classical muslim view', in George Nicholas Atiyeh (ed.), The Book in the Islamic World (Albany: State University of New York Press, 1995), 33-70, at p. 40 (note 47 ).

65 Julia Boffey, 'Bodleian Library MS Arch. Selden. B.24 and definitions of the "household book", in Edwards Gillespie and Ralph Hanna (eds), The English Medieval Book: Studies in Memory of Jeremy Griffith (London: British Library, 2000), 125-34.

66 Jones, op. cit. (note 23), 36-7.

${ }^{67}$ Max W. Thomas, 'Reading and Writing the Renaissance Commonplace Book: A Question of Authorship', Cardozo Arts and Entertainment, 10 (1992), 665-79.

68 Ann Blair, 'Humanist Methods in Natural Philosophy: the Commonplace Book', Journal of the History of Ideas, 53 (1992), 541-51.
} 
'record a wide range of realia or interesting bits of general information sorted under appropriate subject headings according to the topics and themes addressed' ${ }^{69}$

Another genre of European medieval manuscripts was termed 'booklet'. The 'booklet' was described as a 'self contained unit. . . originated as a small but structurally independent production containing a single work or a number of short works' ${ }^{70}$ According to Robinson the 'booklet' was a third type of manuscript unit: the first type being the 'quire', which was a gathering of conjoint leaves secured one within the other by sewing them together, and the second being the 'pecia', which can be found in European university manuscripts.

A unique genre of medical handbook named Tabula Medicine was in use from the fourteenth century in England. This was a lengthy Latin medical text organised alphabetically by headings, and space was left after each entry for expansion and addition by subsequent generations of practitioners and users of the manuscript. ${ }^{71}$ Another medieval use or genre of notebooks was identified and described by Bos and Mensching who recorded dozens of medical glossaries (synonyms of medicinal substances and terms) written in Hebrew, Judaeo-Arabic, Persian, Ladino, Yiddish and other languages. ${ }^{72}$ Interestingly enough, we found only one such glossary in the UK Genizah collections. ${ }^{73}$

Thus, throughout history, all of the various genres of notebooks and their contents, including prescriptions, seem to have been intended for personal use; they are usually shorter than books, untidy and often written in a barely legible scrawl.

In examining the medical notebooks discovered in the Genizah we find evidence of unique features that distinguish them both from other medical books and practical prescriptions:

- The text in notebooks is actually longer than in prescriptions and contains a few or many recipes;

- The external dimension is on average smaller than that of the medical books; in many cases, parts of the fragments are written in a different handwriting, ${ }^{74}$ sometimes in different kinds of ink;

- The recipes in the notebooks have names and do not usually have blessings (benedictions), which is similar to what is found in books but unlike practical prescriptions; ${ }^{75}$

- The absence of blessings indicates that the recipes in notebooks were written in order to record the recipes and not to instruct the pharmacists how to prepare the formulae and use them for treating patients on the spot;

${ }^{69}$ Zachary Schiffman, 'Montaigne and the Rise of Skepticism in Early Modern Europe: A Reappraisal', Journal of the History of Ideas, 45 (1984), 504-5.

${ }^{70}$ P.R. Robinson, 'The "Booklet”, A Self-contained Unit in Composed Manuscripts', Codicologica, III (1980), 46-69.

${ }^{71}$ This early 'Wiki' style medical book is described in details in Peter M. Jones, 'The Tabula Medicine: an Evolving Encyclopedia', A.S.G. Edwards (ed.) English Manuscripts Studies, 14 (2008), 60-85.

${ }^{72}$ Gerrit Bos and Guido Mensching, 'The Literature of Hebrew Medical Synonyms: Romance and Latin Terms and their Identification', Aleph, 5 (2005), 169-211; Gerrit Bos and Guido Mensching, 'Shem Tov Ben Isaac, Glossary of Botanical Terms nos. 1-18', Jewish Quarterly Review, 92 (2001), 21-40.

73 Efraim Lev and Zohar Amar, 'A Medieval Judaeo-Arabic Glossary of Drug's Names in the Taylor-Schechter Genizah Collection, Cambridge', Journal of Semitic Studies (forthcoming).

${ }^{74}$ Mosseri I.124.2; Mosseri I, 127.2; Mosseri IX.118; T-S K 25.83; T-S Ar. 35.226; T-S Ar. 43.56; T-S Ar. 45.40; T-S AS 148.111; T-S NS 224.149.

75 T-S Ar. 42.67; T-S Ar. 45.40. 
- Occasionally the overleaf is blank, ${ }^{76}$ and sometimes the verso is inverse to the recto (the 'top' of one side is the 'bottom' of the other); ${ }^{77}$ in other cases the content of the verso differs completely from the recto ${ }^{78}$ even when they both deal with medicine (for example, in one case, ${ }^{79}$ an Aramaic ketuba appears on the back of the fragment; the common practice of recycling (secondary use) of writing materials is evident in this instance);

- Sometimes the content on one side is divided into two to four columns, ${ }^{80}$ in one case the recipes were crossed out; ${ }^{81}$

- In most cases, the text is written in a vulgar style and is scrawled, ${ }^{82}$ while the line arrangement is usually sporadic and unfixed, with margins of various sizes, similar to prescriptions and different from the books. ${ }^{83}$

The majority (forty-nine) of the medical notebooks found in the Genizah are written in Judaeo-Arabic, which undoubtedly was the vernacular at the time and clearly attests to the fact that these notebooks were written and used by Jewish practitioners. Only a few notebooks (eight) were written in Arabic and one in Hebrew. In other cases the content is in multiple languages (Hebrew, Arabic and Judaeo-Arabic). ${ }^{84}$ Some notebooks were written on vellum. ${ }^{85}$

The study of Genizah medical notebooks and their analysis led me to draw the following diagram in which I have attempted graphically to locate our documents between the theoretical literature and the medical practice of the practitioners in medieval Cairo (figure 3). ${ }^{86}$

As mentioned at the beginning of the article, the main question which puzzled me was who wrote those medical notebooks found in the Genizah, and for what purpose. From studying the history of notebooks and their uses throughout the ages in general and the medical notebook in particular, I suggest the following options:

- The medical notebooks of the Genizah might have been the way the Jewish Cairene practitioners (physicians or pharmacists) kept their favourite recipes which were acquired from other physicians [A - in the diagram of figure 3] and medical books [D], or recorded when practising in local hospitals [B];

- They might have been written by medical students who recorded the medical knowledge of their preference which they learnt from reading books [D] or picked up orally from famous physicians with or under whom they worked [A]. An earlier (classical) feature that was found in a Pseudo-Galen book, Avoiding Grief, strengthens the last two options. In chapters thirty-two and thirty-three the author describes how he collected the recipes he includes in his book. He comments on his good fortune in being

\footnotetext{
${ }^{76}$ Mosseri I, 113; T-S Ar. 45.40; T-S NS 90.64; T-S NS 163.116; T-S NS 164.159; T-S NS 324.128; T-S NS 339.62 .

${ }^{77}$ Mosseri I, 127.1; Mosseri I, 127.2; T-S NS 91.6; T-S NS 224.226; T-S NS 265.62.

${ }^{78}$ Mosseri I, 114.2; Mosseri I, 127.1; Mosseri I, 127.2; T-S K 25.83; T-S Ar. 39.451; T-S Ar. 45.21; T-S AS 148.111 .

79 T-S NS 264.27.

80 T-S Ar. 39.451; T-S NS 90.64; T-S NS 264.27.

81 T-S Ar. 35.226.

82 T-S NS 225.108.

83 T-S Ar. 45.40.

${ }^{84}$ Mosseri, I, 126.1; Mosseri I, 127.1; T-S NS 91.6; T-S NS 164.159.

85 NS 163.116; NS 265.62; Ar. 50.171; Or. 1080 7.17; T-S NS 224.226.

86 The purpose of the diagram is to enlighten the discussion and the conclusion and vice versa.
} 


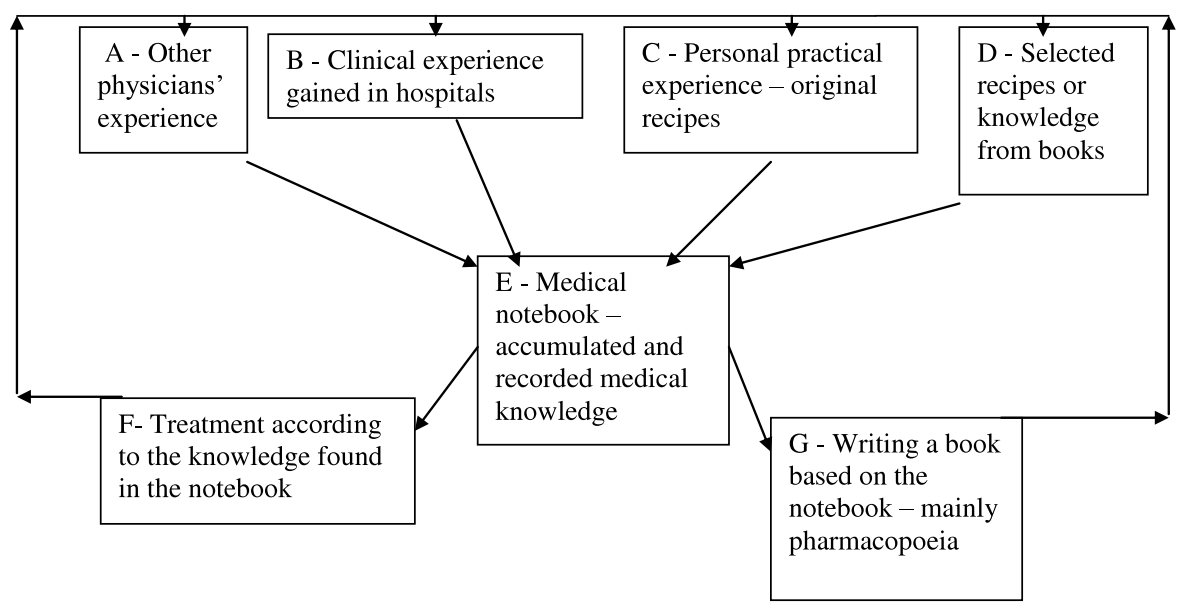

Figure 3: Practical medical notebooks: a diagram.

able to obtain most of the prescriptions from a rich man in Asia Minor who planned to assemble the best collection of recipes in the world, mainly copied from parchments; ${ }^{87}$

- Medical knowledge, mainly recipes, was collected by ordinary people. During this period they may have taken a great interest in medicine and some families might have owned notebooks filled with medical advice and recipes for their personal use $[\mathrm{C}] ;^{88}$

- Traditional healers ${ }^{89}$ were another group of community members who collected such recipes in notebooks for their professional needs and use. Jones, who studied late medieval English medical and commonplace books, wrote on this issue:

It will be as well to remember that medical practice was not just for professionals. It was not monopolized by those for whom medicine was a way of making a living. Nor were medical practitioners the only people who recorded information in manuscripts. Consequently it gives us invaluable insight into medical practice. ${ }^{90}$

This argument stands in our favour since it applies to people in general beyond the more familiar boundaries of time and location. For example, in early modern Yemen, many Jewish families had similar medical notebooks that sometimes included traditional medical knowledge. ${ }^{91}$

Traditional medical writing has been described by Barkai in reference to Spain and North Africa. He states that traditional medicine was not necessarily or exclusively the

\footnotetext{
${ }^{87}$ Veronique Boudon-Millot, 'Un traité predu de Galien miraculeusement retrouvé, le sur l'inutilité de se chagriner: Texte Greg et Traduction Francaise', in Veronique Boudon-Millot, Guardasole Alessia and Magdelaine Caroline (eds), La Science Médicale Antique, Nouveaux Regards (Paris: Beauchesne, 2007), 73-123. at 111 .

${ }^{88}$ Allony, op. cit. (note 32).

${ }^{89}$ Practitioners using knowledge, skills and practices based on the local indigenous experience - in opposition to the learned, licensed doctors.

${ }^{90}$ Peter M. Jones, 'Witnesses to Medieval Medical Practice in the Harley Collection', Electronic British Library Journal (2008), 1-13.

91 Proffesor Zohar Amar, personal communication (November 2010).
} 
domain of ordinary people, and that whoever wrote traditional medical works most probably did not belong to the lower strata of society. ${ }^{92}$ Barkai also differentiates between traditional medical writing and medical books according to the following characteristics:

- Traditional medical writings, including classical and medieval, neither cite nor mention learned medical sources;

- In traditional medicine, the treatment of all diseases and conditions never includes surgical procedures;

- Traditional medicine gives no indication of weights or measures;

- Traditional medicine does not include magic symbols, spells, prayers, or oaths. ${ }^{93}$

From an analysis of our notebooks, most of them seem to contain learned medical knowledge. ${ }^{94}$

A systematic search through Arabic medical books for the source of the recipes found in the notebooks revealed only a few recipes copied from books [D], for example, T-S NS 297.48 from al-Kūhin al-'Attāar al-Isrā'īlì, Minhāj al-Dukkān wa-Dustūr al-'A'yān fì 'A'māl wa-Tarākīb al-'Adwiya al-Nāfi'a li-l-'Insān,;' and from Sābūr Ibn Sahl, alAqrābādhīn al-saghīr (The Small Dispensatory), T-S Ar.44.187, recipe no. 236; ${ }^{96}$ and T-S Ar.45.40, recipe no. $204 .{ }^{97}$ The source for a greater majority of the recipes was not found in printed books or manuscripts. One explanation could be that those recipes were original, perhaps concocted by the notebook owners from their own experience [C]. Another explanation could be that those recipes were passed on to students by word of mouth from their teachers, from other practising physicians or at the hospitals where they worked. In any case, like the point made by Andorlini after studying 260 Egyptian medical papyri of the Classical period, these recipes may have been based not solely on the classical or Arabic medical traditions, but also on local pharmacopoeias, 'developed through inaccuracy or alteration over the centuries'.$^{98}$

A few scholars have raised a number of questions regarding medical notebooks and compendiums of a similar genre. Although they studied notebooks from other periods or different geographical regions, I have noted their questions and will try to reply to them from our experience with the Genizah notebooks. Fortunately enough we can deal with and answer most queries when discussing our findings. When Totelin discussed Pliny's description of the 'private notebook' of Mithridates found by Pompey and said that it included a prescription for an antidote, ${ }^{99}$ she raised the following questions:

Was it the original recipe of Mithridatium? Was it the only recipe contained in the notebook? Was the notebook translated into Latin? Did Pliny have direct access to the notebook or is he reporting something he read, or heard about? ... Was this notebook genuinely recorded by Mithridates or a forgery?

\footnotetext{
${ }^{92}$ Ron Barkai, Science, Magic and Mythology in the Middle Ages (Jerusalem: Van Leer Institute, 1987), (Hebrew), 62.

93 Ibid., 64-5.

${ }^{94}$ For example, T-S K 14.32; T-S Ar. 39.20.

95 al-'Attār, op. cit. (note 43).

${ }^{96}$ Sābūr Ibn Sahl, Dispensatorium parvum (al-Aqrābādhīn al-șaghīr), in Oliver Kahl (ed.), (Leiden/New YorkKöln: Brill, 1994), 145; Oliver Kahl (ed. and trans.), Sābūr Ibn Sahl The Small Dispensatory (Leiden/Boston: Brill, 2003), 123.

${ }^{97}$ Sābūr Ibn Sahl, op. cit. (note 96), 132-3; Kahl, op. cit. (note 96), 113.

98 Andorlini, op. cit. (note 8), 23-33.

${ }^{99}$ Pliny, op. cit. (note 55), 515.
} 
'Unfortunately', Totelin wrote, 'it is impossible to answer these questions'. 100

The medical notebooks identified in the Cairo Genizah collections are not as old as the one mentioned by Pliny, neither do they correspond to such well-known and important historical figures such as Mithridates, Pompey and Pliny. However, they fortunately do supply us with answers to most of Totelin's questions since the recipes in our notebooks are clearly original with only few of them copied from medical books. Moreover, each notebook contained a few recipes which were genuinely recorded and were used by Jewish practitioners in medieval Cairo most of whom are still anonymous.

After studying many Old and Middle English manuscripts of 'household books' and medical books, Green raised many questions including the following: 'Wouldn't women have had access to books in their husbands' libraries, and might not "household books" have been a venue in which men and women might equally share access to medical knowledge?'. Indeed, medical texts and recipes figure as common elements in many 'household books', and in quite a few there are 'vast numbers of gynaecological and obstetrical remedies'. ${ }^{101}$ With regard to this we should point out that among the 61 Genizah medical notebooks found so far, which are dated a few centuries earlier than the 'household books' studied by Green; only one deals with gynaecological conditions. ${ }^{102}$ I therefore suggest that the Genizah notebooks were not written by or for women even though Jewish women might have had access to the medical books and notebooks in their household in medieval Cairo, but most probably not for medical practice. ${ }^{103}$

The main contents of the Genizah medical notebooks are selected recipes, methods of healing and medical theories [E]. The recipes and the medical knowledge collected this way can also give us a clue as to the most prevalent diseases among the members of the community. An analysis of the subjects mentioned in the medical notebooks offers an insight into their daily medical life. ${ }^{104}$ The vast majority of them may be described as pharmacopoeia and can be divided into three groups:

Recipes for the treatment of various diseases. Thirty-five notebooks were identified as pharmacopoeia since they consist of recipes for a range of ailments. This corroborates our finding of vast amount of pharmacopoeias (books) that were identified in the process of studying the medical literature found in the Genizah, and the reconstruction of the medical library of the Jewish practitioners of medieval Cairo;

Treatment of eye diseases. Two fragments were in the literary style of a pharmacopoeia, ${ }^{105}$ but the recipes mainly concern eye diseases. They were consequently identified as the part or chapter dealing with eye diseases in a private

${ }^{100}$ Laurence M.V. Totelin, 'Mithradates' Antidote - A Pharmacological Ghost', Early Science and Medicine, 9 (2004), 1-19.

${ }^{101}$ Monica H. Green, Making Women's Medicine Masculine: The Rise of Male Authority in Pre-Modern Gynaecology (Oxford: Oxford University Press, 2008), 192-3.

102 T-S Ar. 45.21, dealing with treatment of women's complaints, including menorrhagia.

103 It should be noted that Goitein briefly wrote about the role of women in medicine recorded in the Genizah, for example 'the little woman doctor'. According to him, these women mainly fulfilled a role in the female society of the Genizah period, some were specialists for the removal of hair from the bodies of ladies, while others served as midwives; Goitein, op. cit. (note 13), I, p. 127-8, III, p. 63-4, 232.

${ }^{104}$ I intend to discuss separately some of those genres (based on fragments of books and notebooks found in the Genizah) in future publications, mainly pharmacopeias, eye diseases, and materia medica.

105 Each pharmacopoeia in the Arabic medical literature has its own structure and order of chapters, where formulations are grouped in various ways. In general, pharmacopoeias appear to have no truck with the head-totoe arrangement usually found in medical encyclopedias. In most cases they present compound drugs according to the traditional arrangement by formulation; Levey op. cit. (note 2), 72. 
pharmacopoeic notebook, similar to the parts found in Arabic medical books by authors such as al-Kindī (ninth century), ${ }^{106}$ Ibn Abī al-Bayān, ${ }^{107}$ and al-Kūhin al-'Attāar alIsrā'î̀î. ${ }^{108}$ I elaborate on this issue in the commentary to the first fragment edited below (T-S K14.32);

Specialised recipes. A few fragments were identified as dealing with skin diseases (two), coughs and colds (one), dentistry and oral hygiene (one), gynaecological conditions (one), and even traditional medicine (two). Seven fragments concern the actions and uses of simples and therefore can be described as materia medica. ${ }^{109}$

Three notebooks found in the Genizah, besides the above-mentioned pharmacopoeias on the treatment of eye diseases, dealt with ophthalmology which is discussed in detail below. A similar situation emerged with regard to the medical books found in the Genizah. Other fragments concern general medical texts (not recipes) (six), dietetics (one), hygiene (one), alchemy (one), and astrological traditional medicine (one).

As mentioned before, a unique finding is a fragment containing fifteen identified medicinal substances and their synonyms and was described as a medical glossary. ${ }^{110}$

Very few medical authorities are referred to or quoted by the writers of the medical notebooks in the Genizah. The few that I did find are classical authors such as Galen ${ }^{111}$ and Arab authors such as al-Rāzī, ${ }^{112}$ Ibn Sīnā ${ }^{113}$ and Ibn Māsawyah (eighth-ninth century). ${ }^{114}$ This is unlike the practice of authors of medieval medical books, who quoted copiously from medical authorities in their writings. ${ }^{115}$

Last but not least is the personal aspect (experience): only a few such cases were recorded; in one example, the author of one of the recipes for the treatment of eye diseases ${ }^{116}$ used the expression mujarrab (tried). The second example is found in the first fragment edited below (T-S K14.32), in which the author wrote personal remarks such as 'marvelous' and 'see great benefit' like many authors of Eastern medieval pharmacopoeias who often concluded their recipes with such remarks. ${ }^{117}$

\section{Edition of the Genizah medical notebooks}

To demonstrate the variety of medical notebooks found in the Genizah collection, I have chosen and edited three fragments for publication written, respectively, in Hebrew, JudaeoArabic and Arabic.

\footnotetext{
${ }^{106}$ Martin Levey, The Medical Formulary or the 'Aqrābādhīn of al-Kindī (Madison: University of Wisconsin Press, 1966).

107 al-Bayān, op. cit. (note 29).

108 al-'Atțār, op. cit. (note 43).

109 This is a well-known genre of medical books in medieval Arabic medical literature, well represented in the reconstructed Genizah's medical library, and of importance since the Classical period, eg., Dioscorides' Materia Medica, Robert Theodore Gunther (trans.), The Greek Herbal of Dioscorides (New York: Hafner Pub. Co., 1959); Albert Dietrich, Dioscorides Triumphans. Ein anonymer arabischer Kommentar (Ende 12. Jahrh. N. Chr.) zur Materia Medica, 1-2 (Gottingen: Vandenhoeck \& Ruprecht, 1988).

110 T-S NS 224.146; Lev and Amar, op. cit. (note 76).

111 TS NS 224.226; T-S Ar. 11.11; T-S Ar. 39.367; T-S Ar. 35.226.

112 TS NS 265.27.

113 T-S Ar. 35.226

114 T-S Ar. 11.11.

115 Sābūr Ibn Sahl, op. cit. (note 96), 11-2; Kahl, op. cit. (note 96), 29-30; Levey, op. cit. (note 106), 7; Chipman, op. cit. (note 2), 18-46.

116 TS Ar. 44.30.

117 Chipman, op. cit. (note 2), 13.
} 
T-S K14.32 (figure 4) - Notebook: Ophthalmology. Hebrew; semi-cursive script with sporadic Tiberian vocalisation; paper; 1 leaf; $16.3 \times 11.1 \mathrm{~cm} ; 21-22$ lines. Recipes for the treatment of eye complaints [fifteenth-sixteenth century]. ${ }^{118}$

T-S K14.32 - (recto) Text (Transcription):

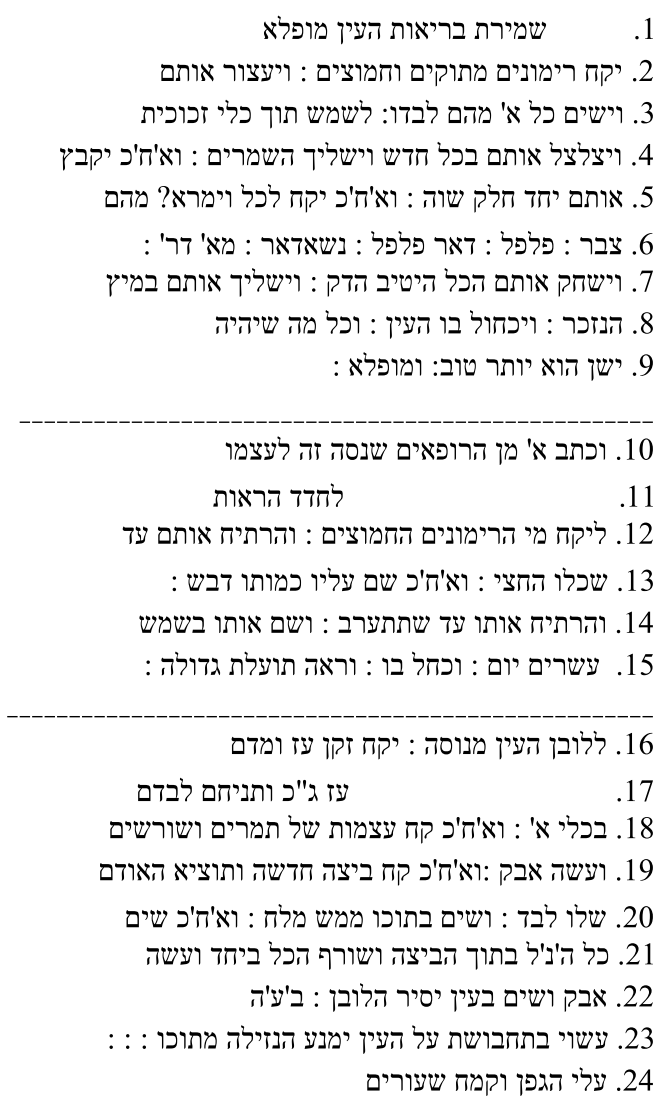

\section{T-S K14.32 - (recto) Translation:}

1. To Preserve the Eye's Health, marvelous

2. Take pomegranates sweet and sour: squeeze them

3. and put each one, alone, in the sun in a glass jar

4. and strain it every month and discard the yeast: and afterwards assemble

5. them equally together: and afterwards take to all and ??? of them

6. aloe : pepper : long pepper : sal-amoniac : of each one dirham.

7. Grind them all good and thin: throw into the juice

8. mentioned: smear on the eye : and the

9. older/riper the better: marvelous

10. and one of the physicians that tried it on himself wrote,

11. to sharpen the eyesight

12. take the juice of sour pomegranates : boil them until

118 Isaacs, op. cit. (note 13), no. 31; Rebecca J.W. Jefferson and Erica C.D. Hunter, Published Material from the Cambridge Genizah Collections: A Bibliography 1980-97 (Cambridge: Cambridge University Press, 2004$), 56$. 


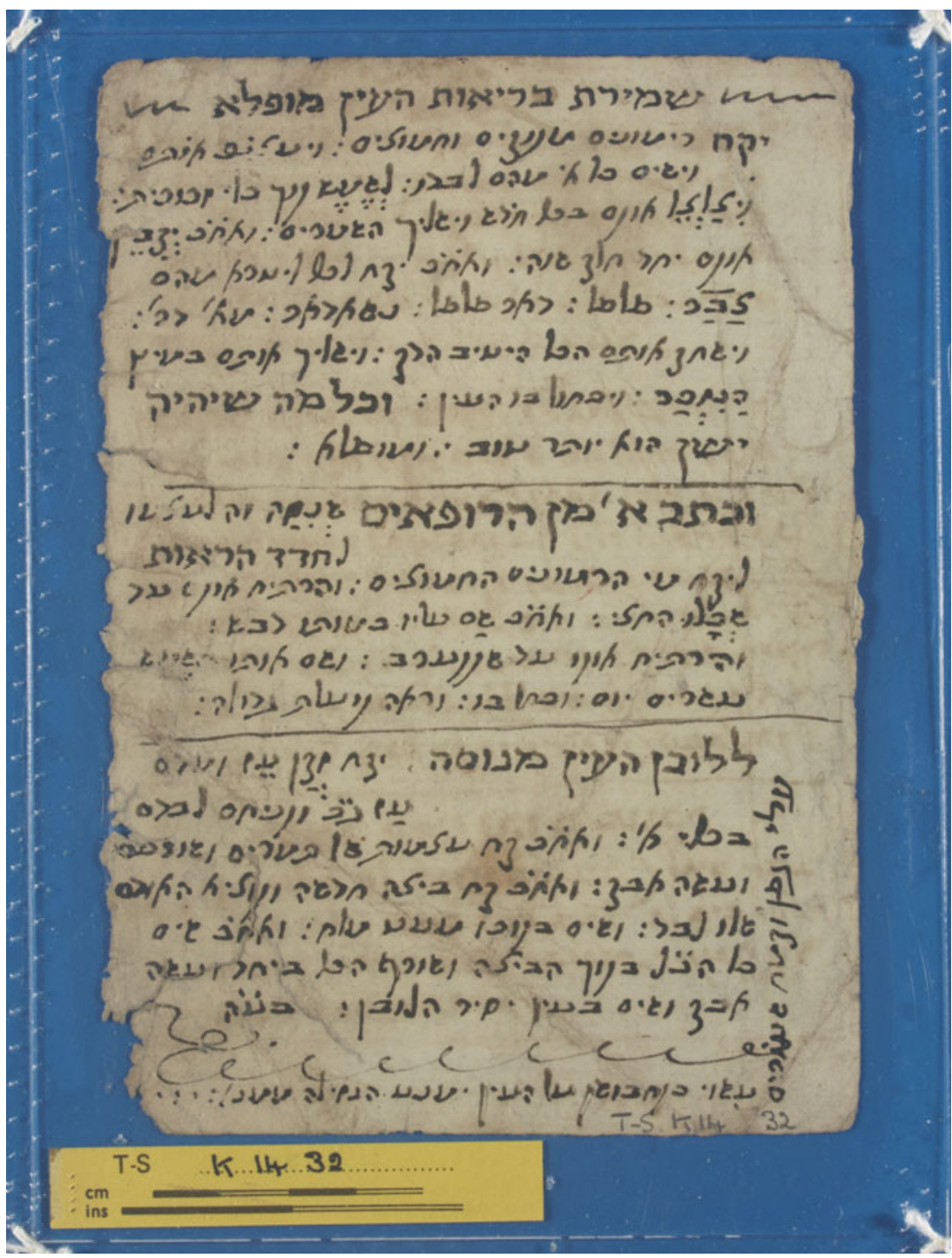

Figure 4: Hebrew ophthalmologic notebook (T-S K14.32).

13. half evaporate : and afterwards add the same amount of honey :

14. boil them until mixed : place in the sun

15. twenty days : smear [the eyes] with it : and see great benefit.

16. For the whiteness of the eye tested: take goat's beard and blood 17. of goat also and place them separately

18. in one jar : and afterwards take dates' kernels and roots

19. and make powder : and afterwards take a fresh egg and extract its red

20. only : add some salt to it: and afterwards place

21. it all in the egg and burn it together and make 
22. powder and put in the eye and it will extract the whiteness : with God's help

23. Made as a dressing on the eye it will prevent leaking of it ::::

24. vine leaves and barley flour

\section{Commentary}

Certain features attest to the identification of this fragment as a notebook. First, the setting of the information in the fragment is less formal than in a book. Second, the fragment is eclectic in character: the recipes are not set out in any specific/systematic or logical order (two recipes bear the name of an ailment in the first line; and one starts with 'One of the physicians...'). However, the fragment was written by a single author (one hand) and all the recipes (three on one side and three more on the verso) are for the treatment of eye diseases. The medicinal substances mentioned in these recipes are varied and include many inorganic substances such as salt, animal products such as honey, goat (beard and blood) and egg. The rest are plants (pomegranates sweet and sour, aloe, pepper, long pepper, salamoniac and dates). ${ }^{119}$ Most of these are known to be used for such treatments; however, some substances such as zinc which were normally used to treat eye diseases are missing from these recipes.

The instructions are detailed and seem professional, although most of the recipes do not have specific weights and measures, unlike those in books and practical prescriptions. At least one of the recipes, the third in fact, presents traditional medicine on account of the substances recorded, mainly goat (beard) and goat (blood), which would suggest that this notebook is an example of traditional medicine used by the people portrayed in Genizah manuscript. The author inserts a personal comment into almost every recipe, for example, superlatives such as 'marvelous' and 'see great benefit'. The expression 'may God help us', is formulaic closing typical of medical as well as other kinds of prescriptive texts.

In general, the people portrayed in Genizah manuscripts suffered from eye diseases just like their ancestors, ${ }^{120}$ for the most part because of the hot climate. ${ }^{121}$ Since early times, eye diseases have been a major medical problem in Egypt. The relatively large number of medical books found in the Genizah dealing with ophthalmology, and the fact that eye diseases were the most important issue in medical notebooks, attest to this assertion.

Although there were differences between the various cultures in which some evidence of treatment for eye diseases has survived, such as in Assyria, Babylonia and Egypt, many of their ophthalmologic practices were more similar than dissimilar. ${ }^{122}$ Important information regarding eye diseases and their treatment comes from ancient Egyptian sources; a chapter of the Ebers Papyrus (sixteenth century BC) is devoted to eye disorders. ${ }^{123}$ The lotions described in the papyrus contained cream and milk; however, the salves (collyrium) contained materials such as antimony, cooper vitriol, goose grease,

\footnotetext{
119 See entries in Lev and Amar, op. cit. (note 41).

120 Arlington Colton Krause, 'Assyro-Babylonian Ophthalmology', Annals of Medical History, (New Series) 6 (1934), 42-55; Julius Hirschberg, The History of Ophthalmology, Frederic C. Blodi (trans.), 11 vols, (Bonn: Wayenborgh, 1982 and 1985); Harald Nielsen, Ancient Ophthalmological Agents: A Pharmaco-Historical Study of the Collyria and Seals for Collyria Used During Roman Antiquity, As Well As of the Most Frequent Components of the Collyria (Odense: Odense University Press, 1974).

121 John Sandford-Smith, Eye Diseases in Hot Climates (London/Boston: Wright, 1990), Michael Walters Dols and Sulayman Jamal Adil, Medieval Islamic Medicine: Ibn Ridwān's Treatise 'On the Prevention of Bodily Ills in Egypt' (Berkeley/Los Angeles/London: University of California Press, 1984).

122 Daniel M. Albert and Diane D. Edwards, The History of Ophthalmology (Oxford/Cambridge, MA: Blackwell Science, 1996), 1.

123 Cyril P. Bryan, The Papyrus Ebers (London: G. Bles, 1930), 94.
} 
honey, lapis lazuli, myrrh, onion, ox marrow and saltpeter. ${ }^{124}$ According to Albert and Edwards not only were eye problems common, but their treatment was given some priority. ${ }^{125}$ Estes found that $11.2 \%$ of all recipes mentioned in the Ebers Papyrus were for eye disorders. ${ }^{126}$ The most commonly recommended substances for eye diseases are, asafetida, balm of Mecca, blood, dung, frankincense, galena, malachite, marrow, myrrh, ochre (red) and ochre (yellow). ${ }^{127}$

The people in the Eastern medieval world continued to suffer from eye diseases and the doctors had to treat them accordingly. For example, Dols argued that: 'Medieval doctors were general practitioners but might also have a special skill in ophthalmology, bonesetting, pharmacology, or surgery'. ${ }^{28}$ According to Savage-Smith: 'Ophthalmology was the only area, besides pharmacology, that could be called a specialty'. ${ }^{129}$ And indeed, Arab physicians displayed particular concern and skill in the diagnosis and treatment of eye diseases ${ }^{130}$ most of the Arabic medical compendium has chapters concerned with eye diseases, and many monographs were devoted to eye disorders.

Two early writers who should be mentioned are Hunayn Ibn Ishāq (ninth century) and his teacher Ibn Māsawayh, both being among the first Arab physicians who wrote on this subject. The influential monograph on ophthalmology Ten Treatises on the Eye written by Hunayn was based to a large extent on Greek sources, ${ }^{131}$ yet it showed considerable advancement in knowledge over the Byzantine treatises. Hunayn mentions in his book that he wrote it as a result of requests made by many physicians. ${ }^{132}$ The Iraqi physician al-Kindī in his 'Aqrābādhīn [Medical Formulary], designated 30 drugs for the treatment of eye diseases which was one of the major ailments from which medieval people suffered. ${ }^{133}$ Many other recipes are found in books written by physicians such as Sābūr Ibn Sahl, ${ }^{134}$ Kūhin 'Attāa al-Isrā' '̄ilī135 and Ibn Abī al-Bayān. ${ }^{136}$ One of the most highly regarded of all of the ophthalmological manuals covering 130 eye ailments was written by 'Alī Ibn 'Isa who practiced in Baghdad. ${ }^{137}$ Thanks to the Genizah, we now definitely know that it was widely used by the Jewish physicians in medieval Egypt.

As mentioned above, several dozen fragments of books on ophthalmology have been found in the T-S Genizah collection, many of which have been identified as belonging to 'Alī Ibn 'Isa's Tadhkirat al-Kahhậ̄īn. ${ }^{138}$ A dozen of practical prescriptions also deal with eye diseases.

\footnotetext{
124 Georg Ebers, Papyrus Ebers (Leipzig: W. Engelmann, 1875).

125 Albert and Edwards, op. cit. (note 122), 7.

126 Worth J. Estes, The Medical Skills of Ancient Egypt, 2nd edn (Canton, MA: Science History Publications, USA, 1993).

127 Ibid:; Albert and Edwards, op. cit. (note 122), 8.

128 Dols and Adil, op. cit. (note 121), 36.

129 Savage-Smith, op. cit. (note 2), 948-50.

130 Ibid.

${ }^{131}$ Hunayn Ibn Ishāq, The Book of the Ten Treatises on the Eye, Max Meyerhof (ed. and trans.) (Cairo: Government press, 1928).

132 Savage-Smith, op. cit. (note 2), 948-50.

133 Levey, op. cit. (note 106), 11, 13, 162-86, 190-1, 196, 204-6.

${ }^{134}$ Kahl, op. cit. (note 96) 4, 16. 154, 278, 358, 359, 361, 364, 367, 369, 370, 372, 373, 378.

135 al-'Attāar, op. cit. (note 43).

${ }^{136}$ Dāwūd Ibn Abī al-Bayān, 'al-Dustūr; EI, III, 683; Lev, Chipman and Niessen, op. cit. (note 29).

137 Casey A. Wood, Benevenutus Grassus of Jerusalem, De Oculis (California: Stanford University Press, 1929).

138 'Alī Ibn 'Īsā al-Kaḥhāl, Tadhkirat al-kaḥ̂ālīn, in Fuat Sezgin (ed.) (Frankfurt am Main: for the History of Arabic-Islamic Science at the Johann Wolfgang Goethe University, 1997).
} 
T-S Ar.45.40 (figure 5) - Notebook: Pharmacopoeia. Judaeo-Arabic; Oriental semicursive script; vellum; 2 leaves ( 1 bifolio, mutilated and stained; $13 \times 27.8 \mathrm{~cm} ; 10-15$ lines; $\mathrm{f} .2 \mathrm{r}$ is blank. Recipes for a dressing applied to the liver region and the preparation of berberis tablets (pastilles) [tenth-eleventh century]. ${ }^{139}$

T-S Ar.45.40 - (recto) right. Text (Transcription):

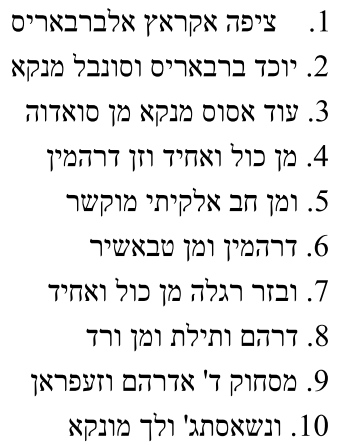

\section{T-S Ar.45.40 - (recto) right. Translation:}

1. Recipe for berberry pastilles

2. Take berberry and clean nard

3. Stick of liquorice clean of the black ones,

4. of each a weight of 2 dirhams,

5 . and peeled seeds of chate melon ${ }^{140}$

6. 2 dirhams, and bamboo chalk

7. and seeds of purslane, of each one

8. dirham and $1 / 3$, and rose

9. crushed 4 dirhams, and saffron

10. and starch and clean lac

\section{T-S Ar.45.40 - (recto) left. Text (Transcription):}

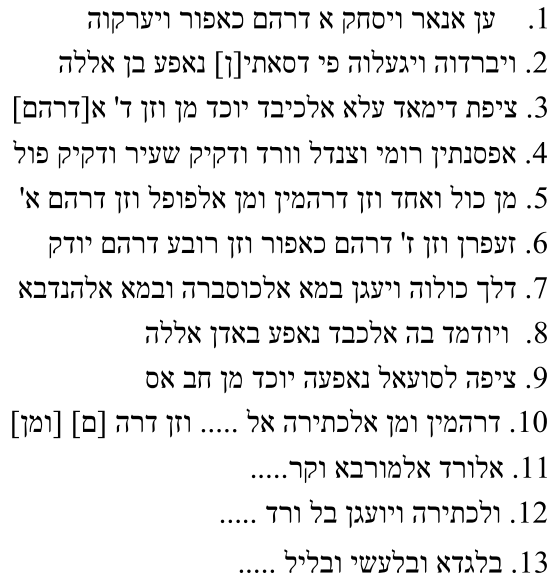

${ }^{140}$ Cucumis melo var. chate; see Zohar Amar and Efraim Lev, 'Watermelon, Chate Melon, and Cucumber: New light on Traditional and Innovative Field Crops in the Middle Ages', Journal Asiatique, 299 (2011), 193-204. 
(a)

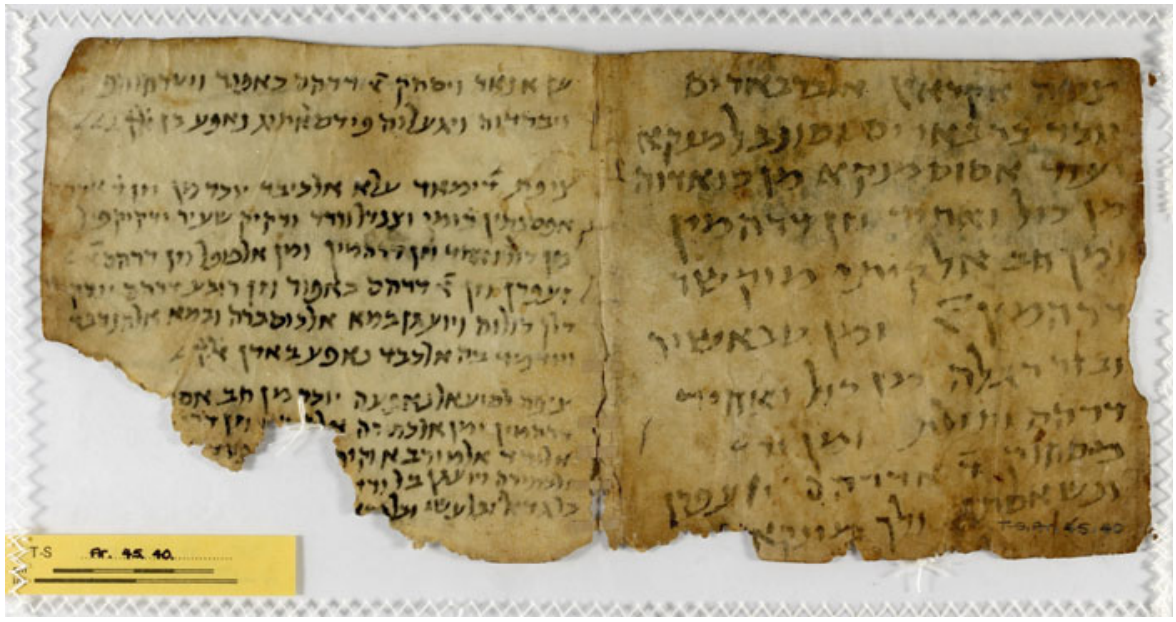

(b)

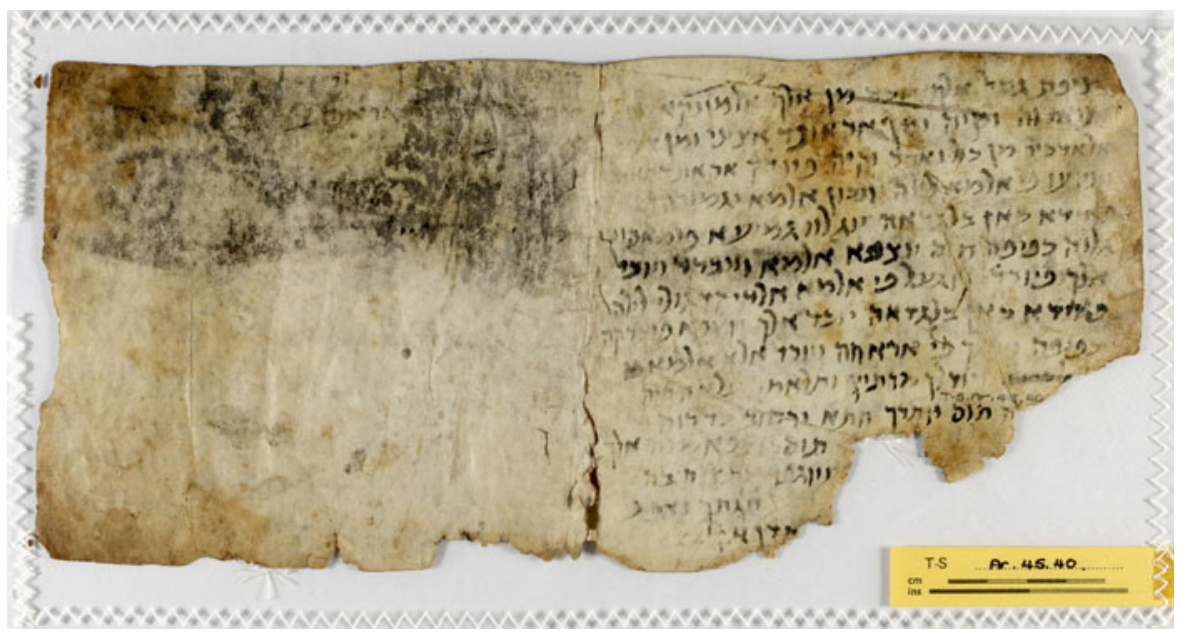

Figure 5: Judaeo-Arabic pharmacopoeic notebook (T-S Ar.45.40).

\section{T-S Ar.45.40 - (recto) left. Translation:}

1. Over fire and crush one dirham camphor and add water to it (dilute) ${ }^{141}$

2. Cool it and place in [two cauldrons] beneficial if God wills

3. Recipe for dressing placed on the liver: take a weight of 4 dirhams

4. Roman absinthian wormwood and sandalwood and rose and barley flour and broad bean flour,

5. of each one a weight of 2 dirhams, and betel palm of weight 1 dirham,

6. saffron of weight 7 dirham, camphor of weight 0.25 dirham. Crush

7. all of it and knead it with coriander water and chicory water

8. and dress the liver; beneficial if God wills

${ }^{141}$ A few drops probably by vaporization and condensation. 
9. Recipe for cough beneficial. Take from seeds of myrtle

10. 2 dirhams, and tragacanth ..... of weight a dirham,

11. rose made as jam and .....

12. tragacanth and knead it with rose [water]

13. in the morning and in the evening and in.....

\section{Commentary}

This fragment is clearly eclectic, and also represents a good example of the form of medical notebooks:

- It consists of at least two bi-folios;

- The recipes have different shapes;

- The handwriting varies;

- The size of the letters of the different recipes is not the same.

One of the recipes is exclusively for the treatment of the liver (according to its title) and the second is for liver ailments (according to contemporary books). On the verso there is a recipe for cleaning lac, which is a major ingredient in one of the recipes.

The medicinal substances listed in these recipes are the following:

(recto) right: berberry, nard, liquorice, chate melon, bamboo chalk, purslane, rose, saffron, starch and lac. ${ }^{142}$ This recipe (berberry pastilles) is similar (same ingredients in a different order) to recipe no. 204 in Sābūr Ibn Sahl, al-Aqrābādhīn al-Saghīr (The Small Dispensatory). According to Sābūr Ibn Sahl it was used for fever, thirst and tumours of the liver and stomach. ${ }^{143}$ These ingredients weighed about twenty-four grams.

(recto) left: 1. Camphor. These two lines are the last part of a recipe the beginning of which is missing (it is probably on the missing bifolio that was the inner part of the notebook). 2. Roman absinthian, wormwood, sandalwood, rose, barley, broad bean, betel palm, saffron, camphor, coriander and chicory. ${ }^{144}$ This recipe for the treatment of the liver has a weight of about twenty-two dirhams (about seventy-seven grams) plus the water. 3. Tragacanth, myrtle, rose (jam and water). ${ }^{145}$ This is an incomplete recipe for the treatment of coughs. In general it might be either lohoch (electuary; Arabic: $l a ' \bar{u} q$ ) or syrup (Arabic: sharāb). Recipes for cough relief in the Arabic medical literature include various combinations (for the synergetic effect) of the mucilages and syrups produced by cooking the fruits or seeds of the relevant plants, or are produced from the gummy sap of particular trees. In our case the rose (jam and water) and gum tragacanth are the ingredients whose main effect on the respiratory system is to soothe irritated membranes; such substances were usually combined with the 'active ingredients (that are missing in our case). ${ }^{146}$

T-S Ar.42.67 (recto) (figure 6) - Prescriptions of lesser and greater triphala, Arabic; Ruq'ah script; paper; 1 leaf; stained; $10.6 \times 14.8 \mathrm{~cm} ; 8$ lines; verso is blank. Two formulae [eleventh-twelfth century]. ${ }^{147}$

\footnotetext{
142 See entries in Lev and Amar, op. cit. (note 41).

143 Sābūr Ibn Sahl, op. cit. (note 96), 132-3; Kahl, op. cit. (note 96), 113.

144 See entries in Lev and Amar, op. cit. (note 41).

145 Ibid.

${ }^{146}$ Leigh Chipman, 'How Effective were Cough Remedies Known to Medieval Egyptians?', Korot, 16 (2002), $142-3$.

${ }^{147}$ Isaacs, op. cit. (note 13), no. 436.
} 


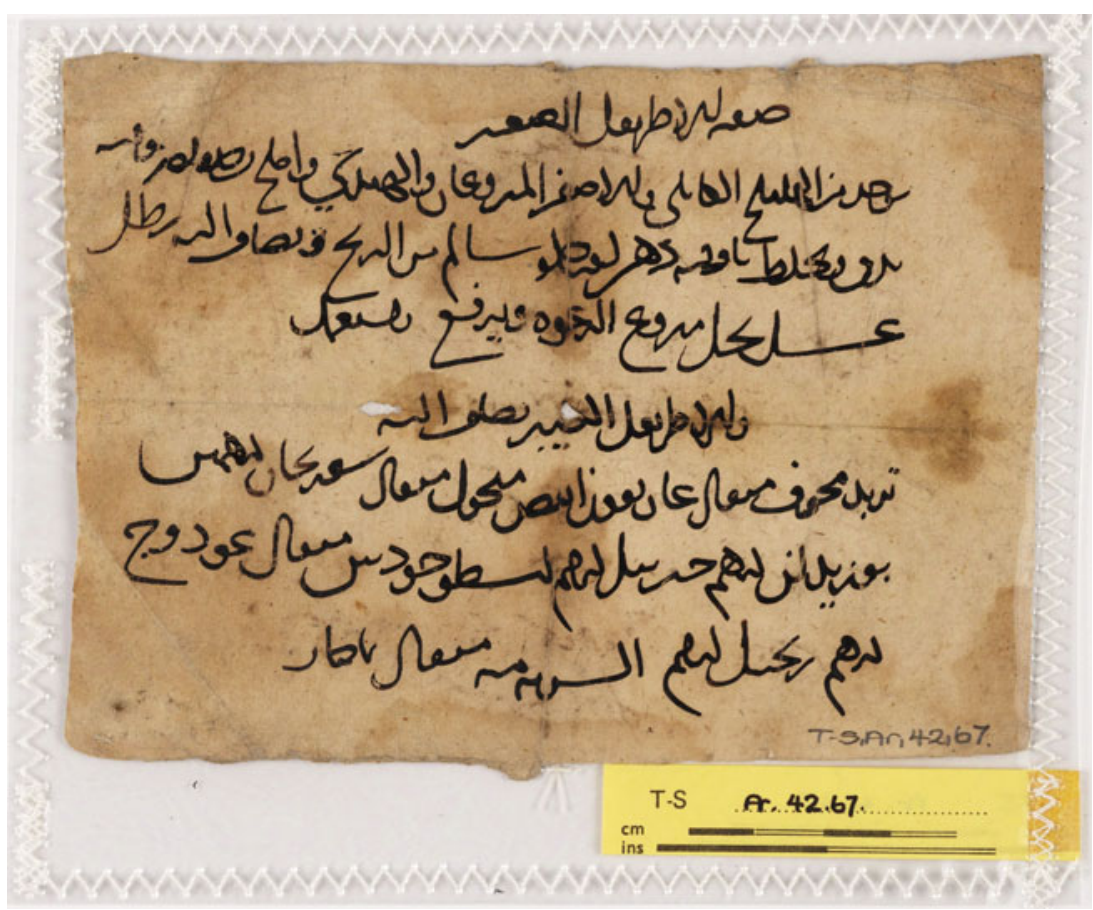

Figure 6: An Arabic notebook consisting of unique prescriptions (T-S Ar.42.67).

T-S Ar.42.67 (recto). Text (Transcription):

$$
\begin{aligned}
& \text { 1. }
\end{aligned}
$$

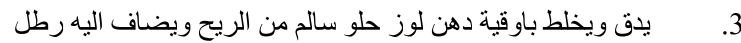

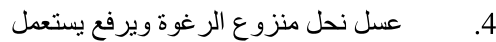

$$
\begin{aligned}
& \text { 6 }
\end{aligned}
$$

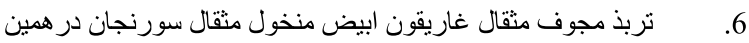

$$
\begin{aligned}
& \text { 7. }
\end{aligned}
$$

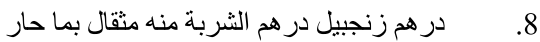

\section{T-S Ar.42.67 (recto). Translation:}

1. Recipe of the lesser triphala

2. Take of cleaned chebulic and yellow myrobalan, Indian [myrobalan] and emblic [myrobalan], half a dirham each;

3. Pound and mix in one ūqiyya of odourless sweet almond oil and add to it one ratl

4. of bees' honey skimmed of froth. Take and use.

5. And the greater triphala, should be added

6. dried turpeth, one mithqāl; sifted white agaric, one mithqāl; meadow saffron, two dirhams;

7. orchid, one dirham; indigo seed, one dirham; lavender, one mithqāl; aloeswood

8. one dirham; ginger one dirham. The dose is one mithqāl in hot water 


\section{Commentary}

The medicinal substances mentioned in these recipes are as follows:

- Lesser triphala - myrobalan (chebulic, cleaned), myrobalan (yellow), myrobalan (Indian), myrobalan (emblic), almond (sweet, oil), honey (bees' - skimmed of froth);

- Greater triphala - turpeth (burnt/dried), white agaric (sifted), meadow saffron, orchid, indigo (seed), lavender, aloeswood, ginger. ${ }^{148}$

Their main medical characteristic is the treatment of stomach ailments, especially as a purgative. The pharmacological aspect of concocting the recipe is to grind all of the ingredients, then pound and mix them in one ūqiyya (33.85-37.5 grams) ${ }^{149}$ of odourless sweet almond oil and add to it one ratl of bees' honey skimmed of froth.

The total weight of the recipe described in this prescription is: 1. Lesser triphala -490 grams; 2. Greater triphala - add thirty-three grams; altogether 522 grams. Since the author wrote that 'The dose is one mithqāl in hot water' the amount here is good for 111 doses. This leads to the assumption that this recipe was more for the use of pharmacists.

Triphala (atrīfal, ițrifil, itrift, itriful, 'itrifful in Arabic), is a compound laxative. Here it is probably the Tibetan/Indian drug tripala. According to Sbath and Avierinos, it is 'confections made of the three kinds of myrobalans, chebulic, embolic, and belleric'. ${ }^{150}$ Levey believes that it is the 'Arabised' form of the Indian name. It applies to three kinds of myrobalans: kabul, belleric and embolic, that 'strengthens the nervous organs and aids the organs of nutrition in regard to waste excesses'. Usually they are made up of equal weights due to their similar usefulness and strength. ${ }^{151}$ A prescription for yellow 'itrīful was found in the Genizah (T-S Ar.41.81). It was used for the treatment of piles (haemorrhoids) and contained honey, myrobalan (black, yellow and chebulic myrobalan), bdellium, sugar candy, caper-root, leek seed, camel dung, long aristolochia and harmala seed.

Maimonides mentions the great 'itrinful in his books which was used for strengthening various organs, especially the heart and the senses, for delaying aging, and helping in coitus. ${ }^{152}$ It contains: parsnip, balsam bark, ginger, musk, rose seed, galangal, almonds, almond oil, aloe wood, anise, borage, cardamom, carrot seed, long pepper and myrobalan [Indian, beleric, embelic, yellow]. ${ }^{153}$

\section{Conclusion}

As mentioned before, the identification of Genizah fragments that belong to the genre of medical notebooks occurred during the course of our study of the above-mentioned UK Genizah collections. These documents provide the most direct evidence we have

\footnotetext{
148 See entries in Lev and Amar, op. cit. (note 41).

149 Goitein, op. cit. (note 11), II, 267; Hinz, Walther, Islamische Masse und Gewichte (Leiden: Brill, 1970).

${ }^{150}$ Paul Sbath and Christo D. Avierinos, Deux traits medicaux (Le Caire: Impr. de l'Institut français d'archéologie orientale, 1953).

${ }^{151}$ Martin Levy, The Medical Formulary of Al-Samarkandī (Philadelphia: University of Pennsylvania Press, 1967), 69-70.

152 Moshe Ben Maimon (Maimonides), Regimen Sanitatis, in Sussmann Muntner (ed.), (Jerusalem: Mosad Harav Kook, 1957), (Hebrew). 3:11.

153 Ibid., 3:1; Moshe Ben Maimon (Maimonides), The Medical Aphorisms of Moses Maimonides, in Fred Rosner and Sussmann Muntner (eds) (New York: Yeshiva University Press, 1970), 21:72; Moshe Ben Maimon, (Maimonides), Sexual Life (On the Increase of Physical Vigour), in Muntner Sussmann (ed.) (Jerusalem: Geniza, 1965). (Hebrew). Introduction, Section 2.
} 
for preferred practical medical recipes because they record the choices of medical practitioners in medieval Cairo.

There is no clear-cut answer to the first research question: Who wrote the notebooks and for what purpose? However, a few options were suggested:

- Cairene Jewish practitioners;

- Medical students (both keeping preferred recipes);

- Traditional healers (recipes kept for professional needs and uses);

- Ordinary people (recipes kept for personal or family use). ${ }^{154}$

It seems as though there is no single right answer; moreover, each notebook is a different case and therefore generalisation is not an option in this matter. The language of preference for the authors of the medical notebooks in the Genizah was undoubtedly Judaeo-Arabic; therefore, they were evidently Jewish. The bulk of the information contained in the notebooks is medical recipes; there are also methods of healing and few notebooks on medical theories.

The subject matter of the Genizah medical notebooks shows that they were mostly an eclectic combination of recipes which their owners had probably heard about from their teachers [A, see diagram in figure 3], learned at the hospitals where they worked [B], prescribed to their patients [C] or copied from books they read [D]. Although the medical notebooks found in the Genizah are not as complete as the medical commonplace books from fifteenth century England that were studied by Jones, we can learn from his research studies about their characteristics which in certain cases were similar. For example, with regards to the sources of the writer's medical knowledge, he found that it was derived 'from personal experience to what he had seen or heard from other practitioners, to what he had read in the works of others'. 155

As for the third question about the kind of medical knowledge recorded in the notebooks and their topics, it was found that the foremost medical genre mentioned in the notebooks was pharmacopoeic, namely the collection of recipes for the treatment of various diseases. There are also a few notebooks on materia medica [E]. Regarding specialised notebooks, eye diseases are first, followed by skin diseases, coughs and colds, dentistry and oral hygiene and gynaecological conditions. As for where the recipes originated, since we have not succeeded in identifying the source of the great majority of recipes either in printed books or in manuscripts, they appear to be original. As mentioned above a similar point was made by Andorlini about the contents of Egyptian medical papyri of the classical period. ${ }^{156}$

From the bibliographical survey we learn that the genre of notebooks and other such compendiums is not new. Notebooks had been in use in a number of ways since classical times, but we do have some historical allusions as to their uses for medical purposes. As part of the oral and written transmission of knowledge, teachers in Early Islam based their lectures and seminars on "collections" of data and "lecture scripts" that were arranged in

\footnotetext{
154 Based on an in-depth study of the Genizah's culture, medieval medical atmosphere, Jewish and Muslim writings, and ethno-medicine and ethno-pharmacology in contemporary Middle Eastern societies and ethnic groups.

155 Jones, op. cit. (note 23), 36-7.

156 Andorlini, op. cit. (note 8), 23-33.
} 
notebooks. ${ }^{157}$ Notebooks were also a humanistic method of storing information including realia, medical synonyms and recipes, for easy access. ${ }^{158}$

The writers of the medical notebooks in the Genizah concentrated mainly on the practical medical knowledge they wanted to record, probably for their future use as amateur physicians, students, traditional healers or professional practitioners $[\mathrm{F}]$. Hence, most of the notebooks are pharmacopoeias containing recipes for various ailments, a specific disease or organ, and materia medica; only a few notebooks are about medical theory. Theoretical knowledge was extensive and important for the training of practitioners and accessible in their own libraries or even homes, but it was less central to the daily routine of treating patients. Notebooks, in general, were apparently meant to serve as memoranda, be it for a scholar or a practitioner. In the case of physicians or pharmacists, notebooks had a practical aim - to allow the practitioner ready access to the required medical information without resorting to the original books [F]. I argued here that the notebooks were also a form in which some of the earliest and well-known pharmacopoeias were composed. The authors acquired and accumulated practical knowledge and recipes and only later compiled and published this material as books [G]. It was most probably actual practice that drove the practitioner to compile the medical notebook.

I strongly suggest that this genre should be kept in mind when newly discovered manuscripts on medicine and other subject matters are studied.

157 Gunther, op. cit. (note 59), 78.

158 Blair, op. cit. (note 68); Schiffman, op. cit. (note 69); Bos and Mensching, op. cit. (note 72); Thomas, op. cit. (note 67); Robinson, op. cit. (note 70); Boffey, op. cit. (note 65); Jones, op. cit. (note 90); Green, op. cit. (note 101). 